\title{
A Review of Wood Modification Globally - Updated Findings from COST FP14O7
}

\author{
Dennis Jones ${ }^{1 *}$ and Dick Sandberg ${ }^{2}$
}

1 Wood Science and Engineering, Luleå University of Technology, Forskargatan 1, SE-931 87 Skellefteå, Sweden [email: dennis.jones@ltu.se]

2 Wood Science and Engineering, Luleå University of Technology, Forskargatan 1, SE-931 87 Skellefteå, Sweden [email: dick.sandberg@ltu.se]

* Corresponding author

\begin{abstract}
Wood modification (chemical, thermal, impregnation) represents an assortment of innovative processes continually being adopted in the wood protection sector. COST Action FP1407 "Understanding wood modification through an integrated scientific and environmental impact approach - ModWoodLife" was initiated in 2015, with its 4-year programme aiming to investigate modification processing and products design with emphasis on their environmental impacts. Among the final tasks within COST FP1407 was to re-evaluate the current status of wood modification across the member countries. However, it became clear that activities in other European countries needed to be addressed, and as a result, a more extensive evaluation of wood modification processes across Europe was undertaken, as well as determining the activities globally. This paper outlines some of the recent updates in wood modification, along with summarising data collected by the authors from international colleagues and online sources, so providing an evaluation of the overall global position. These figures suggest that wood modification is undergoing a significant increase in production due to demand, with levels of recent growth seemingly suggesting this will continue for the coming years. Based on data gathered, the global commercial production of modified wood is dominated by thermal modification processes, which produce $1,110,000 \mathrm{~m}^{3} /$ year. Among the other commercialised processes, acetylation accounts for $120,000 \mathrm{~m}^{3} /$ year and furfurylation $45,000 \mathrm{~m}^{3} /$ year. A further global production of around 330,000 $\mathrm{m}^{3} /$ year is estimated for other processes, predominantly based on resin-based systems (e.g., Impreg- and Compreg-based processes).
\end{abstract}

Keywords: wood modification, commercialisation, production

This work is licensed under the Creative

Commons Attribution 4.0 International license.

Copyright (C) The Authors 


\section{Introduction}

Wood modification (chemical, thermal, impregnation) represents an assortment of innovative processes adopted to improve the physical, mechanical, or aesthetic properties of sawn timber, veneer or wood particles used in the production of wood composites. This process produces a material that can be disposed at the end of a product's life cycle without presenting any environmental hazards greater than those associated with the disposal of unmodified wood.

As a natural renewable resource, wood is in general a non-toxic, easily accessible and inexpensive biomassderived material. Since ancient times, wood has been used by mankind based on its inherent properties, meaning that a specific part of a tree of particular specie that could be found in the neighbourhood was utilised to achieve the best performance when it was used in construction, for different types of tools, or for purposes not included in the practical tasks of life. Aside from drying, modification of timber has been rare from a historical perspective. Nevertheless, as wood is a natural product that originates from different individual trees, limits are imposed on its use, and the material needs to be transformed to acquire the desired functionality. This has become increasingly evident in the modern and highly industrial era. Modification is thus applied to overcome weak points of the wood material that are mainly related to moisture sensitiveness, low dimensional stability, hardness and wear resistance, low resistance to bio-deterioration against fungi, termites, marine borers, and low resistance to UV irradiation.

Hill (2006) has provided a well-accepted definition of wood modification:

"Wood modification involves the action of a chemical, biological or physical agent upon the material, resulting in a desired property enhancement during the service life of the modified wood. The modified wood should itself be nontoxic under service conditions, and furthermore, there should be no release of any toxic substances during service, or at end of life, following disposal or recycling of the modified wood. If the modification is intended for improved resistance to biological attack, then the mode of action should be nonbiocidal".

The means by which the majority of wood modification systems occur can be shown schematically (Figure 1).

Macro-scale behaviour

water

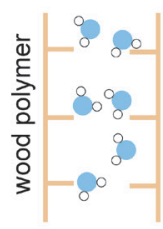

WOOD MODIFICATION
Nano-scale modifications

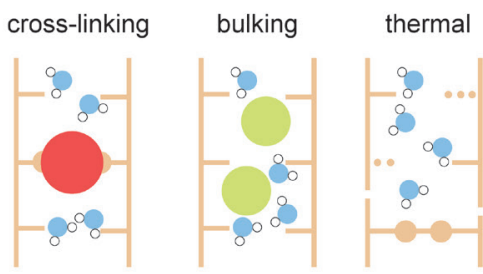

Figure 1: Schematic diagram illustrating the effect of modification.

Active modifications

\begin{tabular}{|l|l|c|c|c|}
\hline lumen filling & cell-wall filling & $\begin{array}{c}\text { reaction with } \\
\text { wood polymers }\end{array}$ & cross-linking & $\begin{array}{c}\text { degradation } \\
\text { of the cell wall }\end{array}$ \\
\hline & & & & \\
\hline
\end{tabular}


The wood modification industry is currently undergoing major developments, driven in part by environmental concerns regarding the use of wood treated with certain classes of preservatives. Several fairly new technologies, such as thermal modification, acetylation, furfurylation, and different impregnation processes, have been successfully introduced on the market and demonstrate the potential of these modern technologies. Figure 2 gives an overview of what can be construed as wood modification.

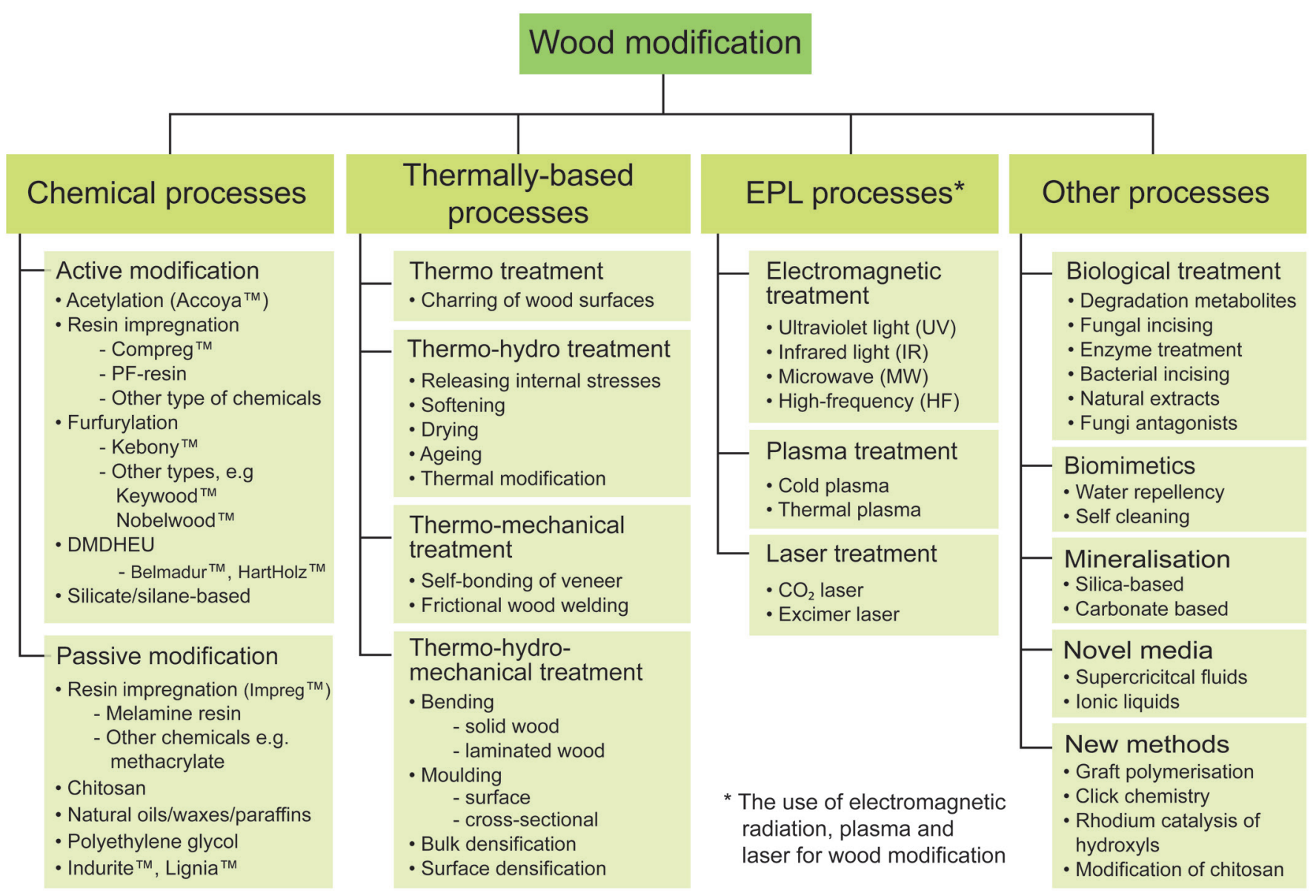

Figure 2: Overview of wood modification processes (modified from Jones et al., 2019).

This paper does not focus on the following areas, which have been reviewed elsewhere:

- treatments aiming to improve wood properties such as fire/flame stability (cf. Lowden and Hull, 2013; Visakh and Arao, 2015),

- preservation of ancient small artefacts (cf. Unger et al., 2001),

- wood particles or disintegrated wood mixed with other polymeric material, such as wood plastic composites (cf. Jawid et al., 2017), or

- modification and derivatisation of extensively mechanically and chemically degraded wood constituents (cf. Huang et al., 2019).

The main reasons for the increased interest during the last decades in wood modification through ongoing research, the industry, and society in general can be summarised as:

1. a change in wood properties as a result of changes in silvicultural practices and the way of using wood,

2. awareness of the use of rare species with outstanding properties, such as durability and appearance, 
3. awareness and restrictions by law of using environmental non-friendly chemicals for increased durability and reduced maintenance of wood products,

4. an increased interest from the industry to add value to sawn timber and by-products, from the sawmill and refining processes further up in the value chain,

5. EU and international policies supporting the development of a sustainable society, and

6. the international dimension on climate change and related activities mainly organised within the frame of the United Nations (UN), such as the Paris Agreement under the United Nations Framework Convention on Climate Change.

\section{COST Action FP1407}

COST Action FP1407 (Understanding wood modification through an integrated scientific and environmental impact approach - "ModWoodLife") aimed to investigate modification processing and products design with emphasis on their environmental impacts. This will require analysis of the whole value chain, from forest through processing, installation, in-service, end of life, second/third life (cascading) and ultimately incineration with energy recovery. The aim of the 4-year Action can be summarised as in Figure 3.

Figure 3: Overview of COST FP 1407.
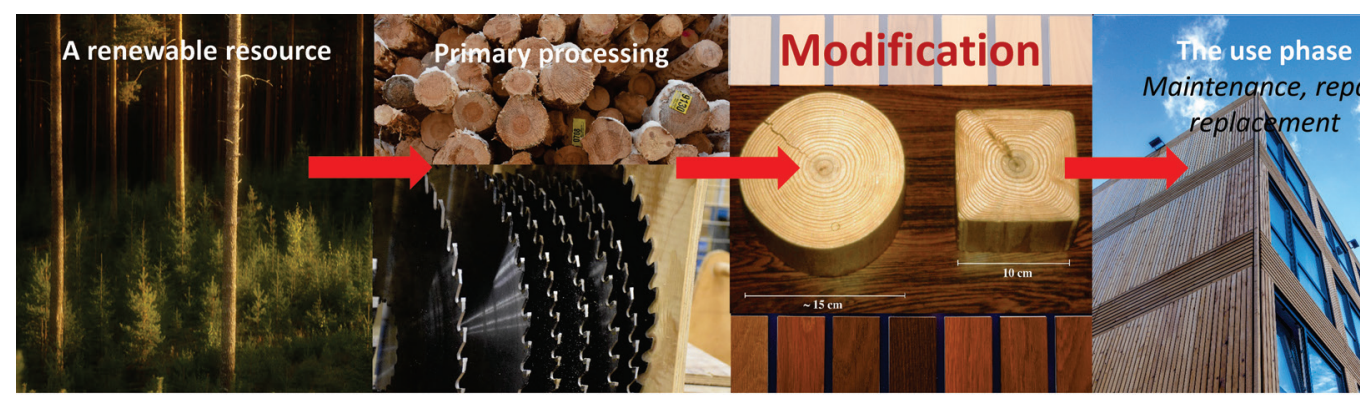
Maintenance, repair replackment
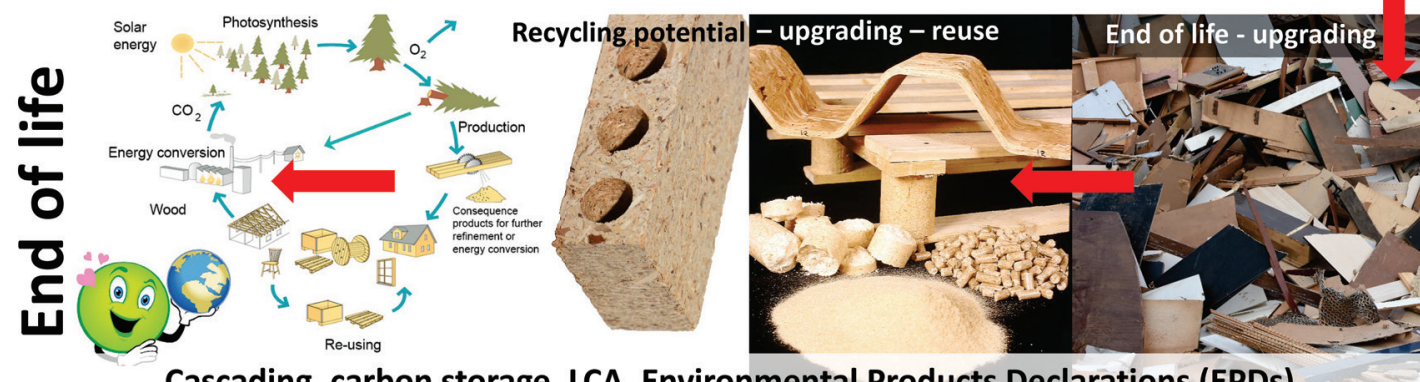

Cascading, carbon storage, LCA, Environmental Products Declarations (EPDs)

The Action also allowed the collection of essential data on the status of wood modification from all participating countries, forming the basis of a publication into how the sector had expended in recent years.

\section{Wood Modification Methods}

The modification of wood has been used as a method to improve the properties of service life of wood for numerous centuries, whether it being the charring or burning of surfaces, or through the application of waxes or oils. An early example of what would today be construed as wood modification was undertaken by Alfred Nobel's father, Immanuel. His work, patented in conjunction with colonel Nikolai Aleksandrovich Ogarev in 1844, considered the impregnation of wood to be used in carriage wheels with a mixture of ferric sulphate and an acid, which was dried slowly in special boxes. After drying, linseed oil and varnish were applied to further 
reduce moisture absorption. The process was also an early example of mechanisation, the process being run by a steam engine, with 36 wheels a day being produced for the Russian army (Tolf, 1976; Meluna, 2009; Carlberg, 2019).

The development of wood modification has focussed on the potential of altering the performance and reduce the risks of wood in service, particularly with regard to dimensional in stability and decay, both of which are strongly influenced by the presence of moisture. Wood in service in interior conditions is usually restricted to moisture contents below $10 \%$, but design or exposure to high moisture conditions can significantly affect its performance. The same is true of wood in Use Classes 2 and 3 as defined within the European standard EN 335 (European Committee for Standardization, 2013), where the moisture content can often exceed $20 \%$ due to atmospheric conditions. A more detailed description of the Use Classes is shown in Table 1, along with definitions of risks and typical product ranges as defined within a product guidance manual produced by the Wood Protection Association in the United Kingdom (WPA, 2012). The risk of decay is then increased, particularly if the exposure is over a prolonged period of time.

Table 1: Overview of Use Classes, as defined according to EN 335 (European Committee for Standardization, 2013) and typical product ranges and their associated risks according to the UK Wood Protection Association (WPA, 2012).

\begin{tabular}{|c|c|c|c|}
\hline Use Class & Biological risk & Typical service exposure & Examples of product ranges \\
\hline $\begin{array}{l}\mathrm{UC} \\
1\end{array}$ & Insect & Internal, with no risk of wetting. & $\begin{array}{l}\text { All timbers in normal pitched roofs except tiling battens and } \\
\text { valley gutter members. }\end{array}$ \\
\hline $\begin{array}{l}\mathrm{UC} \\
2\end{array}$ & Fungi/Insect & $\begin{array}{l}\text { Internal, with risk of occasional } \\
\text { wetting. }\end{array}$ & $\begin{array}{l}\text { Floorboards, architraves, internal joinery, skirtings. All } \\
\text { timbers in upper floors not built into solid external walls }\end{array}$ \\
\hline $\begin{array}{l}\text { UC } \\
3.1\end{array}$ & Fungi/Insect & $\begin{array}{l}\text { External, above damp-proof course, } \\
\text { coated. }\end{array}$ & $\begin{array}{l}\text { Tiling battens, frame timbers in timber frame houses, timber in } \\
\text { pitched roofs with high condensation risk, timbers in flat roofs, } \\
\text { ground floor joists, sole plates (above the damp proof course), } \\
\text { timber joists in upper floors built into external walls. }\end{array}$ \\
\hline $\begin{array}{l}\text { UC } \\
3.2\end{array}$ & Fungi/Insect & $\begin{array}{l}\text { External, above damp-proof course, } \\
\text { uncoated. }\end{array}$ & $\begin{array}{l}\text { External joinery including roof soffits and fascias, barge } \\
\text { boards, etc., cladding, valley gutter timbers, external structural } \\
\text { load-bearing timbers }\end{array}$ \\
\hline $\begin{array}{l}\text { UC } \\
4\end{array}$ & $\begin{array}{l}\text { Fungi/Insect (incl. } \\
\text { termites) }\end{array}$ & $\begin{array}{l}\text { Timbers in permanent contact with } \\
\text { the ground or below damp-proof } \\
\text { course. } \\
\text { Timbers in permanent contact with } \\
\text { fresh water. } \\
\text { Cooling tower packing. } \\
\text { Timbers exposed to the particularly } \\
\text { hazardous environment of cooling } \\
\text { towers. }\end{array}$ & $\begin{array}{l}\text { Cladding, fence rails, gates, fence boards, agricultural timbers } \\
\text { not in soil / manure contact and garden decking timbers that } \\
\text { are not in contact with the ground. }\end{array}$ \\
\hline $\begin{array}{l}\text { UC } \\
5\end{array}$ & Marine borer/ Fungi & $\begin{array}{l}\text { All components in permanent contact } \\
\text { with sea water. }\end{array}$ & $\begin{array}{l}\text { Fence posts, gravel boards, agricultural timbers in soil / } \\
\text { manure contact, poles, sleepers, playground equipment, } \\
\text { motorway and highway fencing / sound barriers and garden } \\
\text { decking timbers that are in contact with the ground. Lock } \\
\text { gates and canal linings. Cooling tower infrastructure (fresh } \\
\text { water). }\end{array}$ \\
\hline
\end{tabular}


A comprehensive review by Thybring (2013) has assessed the decay risk according to levels of moisture exclusion efficiency (MEE), anti-swelling efficiency (ASE), and ASE* (an alternative measure of ASE, where the volume increase resulting from various wood modification methods has been deducted from the dry volume of the unreacted wood). Through the analysis of modification methods undertaken (Table 2), it was possible to estimate threshold levels for MEE, ASE, and $\mathrm{ASE}^{*}$ as well as the respective weight gain required for each treatment (a weight loss when considering thermal modification).

Table 2: Estimated threshold conditions for decay in various wood modifications (Thybring, 2013).

\begin{tabular}{|c|c|c|c|c|}
\hline Modification & Threshold (WPG) & MEE & ASE & $\mathrm{ASE}^{*}$ \\
\hline Acetylation & $20 \%$ & $42 \%$ & $63 \%$ & $60 \%$ \\
\hline Furfurylation & $35 \%$ & $40 \%$ & $74 \%$ & $?$ \\
\hline DMDHEU & $25 \%$ & $43 \%$ & $45 \%$ & $43 \%$ \\
\hline Glutaraldehyde & $10 \%$ & $24 \%$ & $50 \%$ & $48 \%$ \\
\hline Glyoxal & $>50 \%$ & $?$ & $?$ & $?$ \\
\hline Thermal modification & $-15 \%$ & $42 \% ?$ & $46 \% ?$ & $?$ \\
\hline
\end{tabular}

Where WPG - weight percent gain, MEE - moisture exclusion efficiency and ASE - anti-swelling efficiency.

Moisture has been recognised as a key parameter in the infestation and decay of wood by wood destroying fungi. In addition to the supply of oxygen, a favourable temperature, and accessible nutrients, it is an essential factor in the fungal decay of wooden commodities and structures. For many decades, it was therefore essential to define the critical moisture content thresholds allowing the transport and activity of fungal enzymes in the wood cell walls leading to the degradation and severe rot of wooden elements. Nowadays, the wood moisture content is the most important input variable in many service life and performance prediction models, both in engineering and natural sciences (Brischke and Thelandersson, 2014).

The main forms of wood modification (in terms of commercial development) are acetylation, furfurylation, thermal modification, and resin impregnation/polymerisation. There are a range of other modification methods that have been reported (e.g., Rowell, 1983; Hill, 2006) as suggested in Figure 2 and regularly reported in conferences such as the European Conference on Wood Modification (ECWM) and The International Research Group on Wood Protection (IRG).

\subsection{Acetylation}

The acetylation of wood is a chemical modification process in which the electrophilic reagent (most commonly acetic anhydride) is forced by the application of an external pressure to migrate through the wood pits in conifers and through vessels in broad-leaved species, to react with accessible nucleophilic hydroxyl groups in the wood and to diffuse and react deeper into the cell wall (Rowell, 1983). Thus, bulking of the cell wall and loss of hydrophilic hydroxyl groups reduces the moisture uptake, and increases the resistance to swelling and the decay of wood (Hill and Jones, 1996; Hill, 2006). So far, radiata pine has mostly been used commercially due to its low density and open pore structure, but fibres in acetylated fibreboards can be more easily reacted than the solid wood products, and this can favour the use of other species. The simplified reaction of wood components with acetic anhydride is shown in Figure 4. 


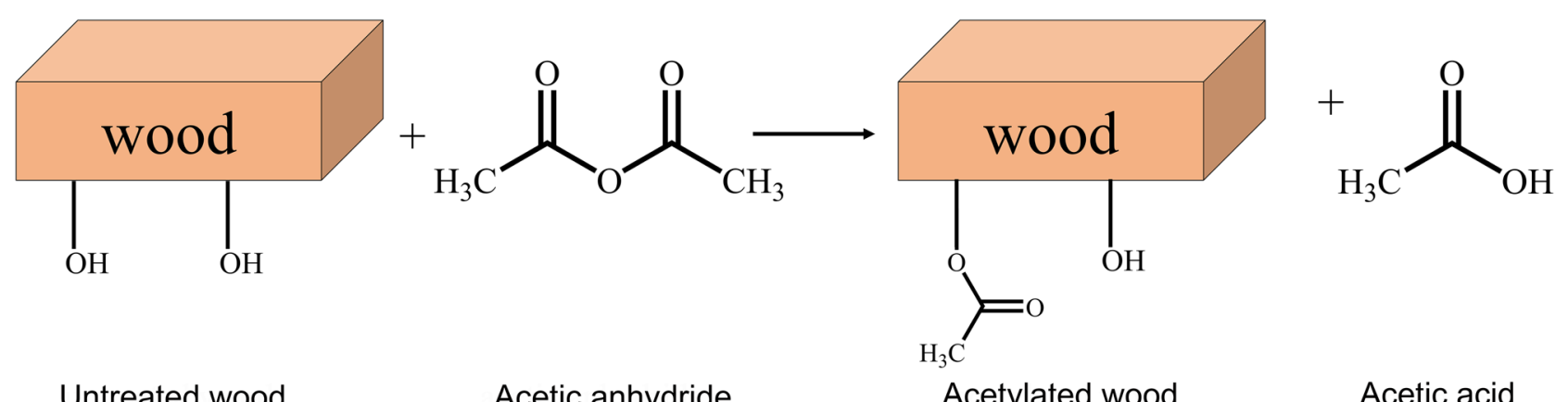

Figure 4: Schematic view of the acetylation of wood.

Many different types of wood have been acetylated using a variety of procedures including European beech (Fagus sylvatica) (Militz, 1991ab), Norway spruce (Picea abies), Scots pine (Pinus sylvestris) (Larsson and Simonson, 1994) poplar (Populus spp.), radiata pine (Pinus radiata) (Bongers and Beckers, 2003), black locust (Robinia pseudoacacia) (Németh et al., 2010), Southern yellow pine, ponderosa pine (Pinus ponderosa) (Goldstein et al., 1961), red oak (Quercus rubra) and sugar maple (Acer saccharum) (Dreher et al., 1964), walnut (Juglans spp.), elm (Ulmus spp.), cativo (Prioria copaifera), Eucalyptus spp. (Rowell, 1984; Ozmen, 2007), rubberwood (Hevea brasiliensis) (Rafidah et al. 2006), poplar (Populus spp.), willow (Salix spp.) (Ozmen, 2007), and oriented strand boards (OSB) (Rowell and Plackett, 1988) as well as other lignocellulosic resources such as bamboo (Phyllostachys bambusoides Sieb. et Zucc) (Rowell and Norimoto, 1987), bagasse (Saccharum officinarum L.) fibre (Rowell and Keany, 1991), jute (Corchorus olitorius) (Callow, 195 1; Andersson and Tillman, 1989), kenaf (Hibiscus cannabinus) (Rowell and Harrison, 1993), wheat straw (Triticum aestivum) (Gomez-Bueso et al., 1999), pennywort (Centella asiatica), and water hyacinth (Eichhornia crassipes) (Rowell and Rowell, 1989). A more detailed overview of species and acetylation conditions is given in Table 3.

Table 3: Summary of selected examples of acetylation.

\begin{tabular}{|c|c|c|}
\hline Species & Acetylation method & Reference \\
\hline \multicolumn{3}{|c|}{ Small and medium scale } \\
\hline African locust bean (Parkia biglobosa) & $\begin{array}{l}\text { Acetic anhydride or acetic acid } / \mathrm{CaCl}_{2} \text {, heating at } \\
120^{\circ} \mathrm{C} \text { for } 3 \text { hours. }\end{array}$ & Azeh et al., 2013 \\
\hline $\begin{array}{l}\text { Caucasian alder (Alnus subcordata C.A. } \\
\text { Mey), Oriental beech (Fagus orientalis } \\
\text { Lipsky) }\end{array}$ & $\begin{array}{l}\text { Acetic anhydride, soak } 24 \text { hours, heating at } 120^{\circ} \mathrm{C} \text { for } \\
90 \text { or } 360 \text { minutes. }\end{array}$ & Akhtari and Arefkhani, 2016 \\
\hline Bagasse fibre (Saccharum officinarum L.) & Acetic anhydride heating $120^{\circ} \mathrm{C}$ for $<4$ hours. & Rowell and Keany, 1991 \\
\hline Beech wood (Gmelina arborea) & $\begin{array}{l}\text { Acetic anhydride or acetic acid } / \mathrm{CaCl}_{2} \text {, heating } 120^{\circ} \mathrm{C} \\
\text { for } 3 \text { hours. }\end{array}$ & Azeh et al., 2013 \\
\hline African baobab (Adansonia digitata) & $\begin{array}{l}\text { Acetic anhydride or acetic acid } / \mathrm{CaCl}_{2} \text {, heating } 120^{\circ} \mathrm{C} \\
\text { for } 3 \text { hours. }\end{array}$ & Azeh et al., 2013 \\
\hline Corsican pine (Pinus nigra) & $\begin{array}{l}\text { Acetic anhydride/pyridine, vacuum for } 1 \text { hour, heating } \\
120^{\circ} \mathrm{C} \text {. }\end{array}$ & Hill and Jones, 1996 \\
\hline $\begin{array}{l}\text { River red gum (Eucalyptus } \\
\text { camaldulensis), Populus spp., white } \\
\text { willow (Salix alba) }\end{array}$ & $\begin{array}{l}\text { Acetic anhydride/dimethylacetamide heating at } 100^{\circ} \mathrm{C} \\
\text { for }<6 \text { hours. }\end{array}$ & Ozmen, 2007 \\
\hline European beech (Fagus sylvatica) & $\begin{array}{l}\text { Acetic anhydride vacuum / pressure, heating at } 120^{\circ} \mathrm{C} \\
\text { for } 9 \text { hours, drying at } 105^{\circ} \mathrm{C} \text { for } 12 \text { hours. }\end{array}$ & Militz, 199la \\
\hline
\end{tabular}


Table 3 (cont.): Summary of selected examples of acetylation.

\begin{tabular}{|c|c|c|}
\hline Species & Acetylation method & Reference \\
\hline European white birch (Betula pendula) & Acetic anhydride heating at $110^{\circ} \mathrm{C}$, various time. & Popescu et al., 2014 \\
\hline Obeche (Triplochiton scleroxylon) & $\begin{array}{l}\text { Impregnation with acetic anhydride, heat } 120^{\circ} \mathrm{C} \text { for } \\
1-5 \text { hours. }\end{array}$ & Adebawo et al., 2019 \\
\hline Dark-bark spruce (Picea jezoensis) & Various methods (catalysed and uncatalysed). & Obataya and Minato, 2009 \\
\hline Jute (Corchorus olitorius) cloth & Acetic anhydride, heating at $120^{\circ} \mathrm{C}$ for 2 hours. & Andersson and Tillman, 1989 \\
\hline Japanese cedar (Cryptomeria japonica) & $\begin{array}{l}\text { Acetic anhydride/supercritical carbon dioxide at } 10-12 \\
\mathrm{MPa} \text {, heating to target } 120-130^{\circ} \mathrm{C} \text { for less than } 63 \\
\text { hours. }\end{array}$ & Matsunaga et al., 2010 \\
\hline Maritime pine (Pinus pinaster) & $\begin{array}{l}\text { Acetic anhydride } 100^{\circ} \mathrm{C} \text { pyridine, } O R \text { vinyl acetate } \\
90-110^{\circ} \mathrm{C} \text { and potassium carbonate catalyst. }\end{array}$ & Jebrane et al., 2011 \\
\hline $\begin{array}{l}\text { White cedar (Thuja occidentalis), sugi } \\
\text { (Cryptomeria japonica) }\end{array}$ & $\begin{array}{l}\text { Acetic anhydride treatment for } 24 \text { hours, heating at } \\
120^{\circ} \mathrm{C} \text { for } 24 \text { hours. }\end{array}$ & Hadi et al., 2015 \\
\hline $\begin{array}{l}\text { Norway spruce (Picea abies), Scots pine } \\
\text { (Pinus sylvestris) }\end{array}$ & $\begin{array}{l}\text { Acetic anhydride, vacuum for } 1 \text { hour, impregnation at } 10 \\
\text { bar for } 1 \text { hour, heating at } 120^{\circ} \mathrm{C} \text { for } 6 \text { hours. }\end{array}$ & Larsson and Simonson, 1994 \\
\hline African oil palm (Elaeis guineensis) & $\begin{array}{l}\text { Acetic anhydride: xylene } 140^{\circ} \mathrm{C} 4 \text { hours, OR acetic } \\
\text { anhydride: toluene } 135^{\circ} \mathrm{C} \text { for } 1 \text { hour. }\end{array}$ & Subagiyo et al., 2017 \\
\hline Rice straw (Oryza sativa L.) fibre & $\begin{array}{l}\text { Acetic anhydride/various catalysts, heating at } 100{ }^{\circ} \mathrm{C} \text { for } \\
0.5 \text { hour. }\end{array}$ & Sun and Sun, 2002ab \\
\hline Radiata pine (Pinus radiata) & Acetic anhydride, vacuum, heating at $110^{\circ} \mathrm{C}$. & Beck et al., 2018 \\
\hline Rubberwood (Hevea brasiliensis) & $\begin{array}{l}\text { Acetic anhydride/pyridine, heating at } 100^{\circ} \mathrm{C} \text { for less } \\
\text { than } 27 \text { hours. }\end{array}$ & Rafidah et al., 2006 \\
\hline Norway spruce, Scots pine & $\begin{array}{l}\text { Acetic anhydride, vacuum, impregnation at } 10 \text { bar for } 2 \\
\text { hours at } 20^{\circ} \mathrm{C} \text { and microwave heating. }\end{array}$ & Larsson-Brelid and Simonson, 1999 \\
\hline Southern yellow pine & Acetic anhydride, vacuum, heating at $140^{\circ} \mathrm{C}$. & Zelinka et al., 2020 \\
\hline $\begin{array}{l}\text { Southern yellow pine, ponderosa pine } \\
\text { (Pinus ponderosa) }\end{array}$ & Acetic anhydride/xylene, heating vacuum, oven heating. & Goldstein et al., 1961 \\
\hline Wheat straw (Triticum aestivum) & $\begin{array}{l}\text { Immersion/drain, } 120^{\circ} \mathrm{C} \text {. Work undertaken at BP } \\
\text { chemicals, UK. }\end{array}$ & Gomez-Bueso et al., 1999 \\
\hline \multicolumn{3}{|c|}{ Industrial conditions } \\
\hline $\begin{array}{l}\text { European beech, European alder (Alnus } \\
\text { glutinosa), lime (Tilia spp.), Maple (Acer } \\
\text { spp.) }\end{array}$ & $\begin{array}{l}\text { Acetylated in the plant of Accsys Technologies in } \\
\text { Arnhem, The Netherlands. }\end{array}$ & Bollmus et al., 2015 \\
\hline European hornbeam (Carpinus betulus) & $\begin{array}{l}\text { Acetylated in the plant of Accsys Technologies in } \\
\text { Arnhem, The Netherlands. }\end{array}$ & Fodor et al., 2017 \\
\hline $\begin{array}{l}\text { Norway spruce, Douglas fir (Pseudotsuga } \\
\text { menziesii) }\end{array}$ & $\begin{array}{l}\text { Acetylated in the plant of Accsys Technologies in } \\
\text { Arnhem, The Netherlands. }\end{array}$ & Bongers and Uphill, 2019 \\
\hline Radiata pine & $\begin{array}{l}\text { Acetylated in the plant of Accsys Technologies in } \\
\text { Arnhem, The Netherlands. }\end{array}$ & Bongers and Beckers, 2003 \\
\hline Southern yellow pine & Eastman Perennial wood $21 \%$ acetyl content. & Wålinder et al., 2013 \\
\hline $\begin{array}{l}\text { Fibres from European aspen, European } \\
\text { beech }\end{array}$ & $\begin{array}{l}\text { Immersion/drain, } 120^{\circ} \mathrm{C} \text {. Work undertaken at BP } \\
\text { chemicals, UK. }\end{array}$ & Gomez-Bueso et al., 1999 \\
\hline
\end{tabular}

\subsection{Furfurylation}

Furfuryl alcohol is a liquid produced from agricultural wastes such as sugar cane and corn cobs. Furfurylation is a process in which a material is impregnated with furfuryl alcohol (or its derivative/prepolymer) in the 
presence of a mild acid catalyst. This is followed by a heat-curing step and drying including recycling of chemicals, where the heating results in a hard and resistant product. The resin contributes to the dark (brownish) colour of the product but, when exposed to direct solar radiation, greying occurs. The first commercial plant for the furfurylation of wood was the Kebony ${ }^{\oplus}$ AS company which started in 2009 in Skien outside Oslo in Norway (Kebony, 2020). It can produce 20,000 $\mathrm{m}^{3}$ /year and another plant has recently been established in Antwerp, Belgium. Foreco Dalfsen in The Netherlands also produces furfurylated solid wood products named Nobelwood $^{\boxplus}\left(1,000 \mathrm{~m}^{3}\right)$ from radiata pine using pre-polymerised furfuryl alcohol resin (Jones et al., 2019). A review of furfurylation was recently published (Mantanis, 2017).

The polymerisation of furfuryl alcohol in wood is a complex chemical reaction, and the question of whether furfurylation is a distinct chemical process remains unanswered. The furfuryl alcohol reacts with itself forming a polymeric structure and possibly with the lignin in the cell walls (Lande et al., 2008; Nordstierna et al., 2008; Gérardin, 2016; Li et al., 2016). Furfuryl alcohol condenses with itself forming water (Figure 5) and a furan condensed product in which the furan units are held together by methylene bridges, although dimethyl ether bridges are sometimes formed (Lande et al., 2008).

(a)

$2 n$

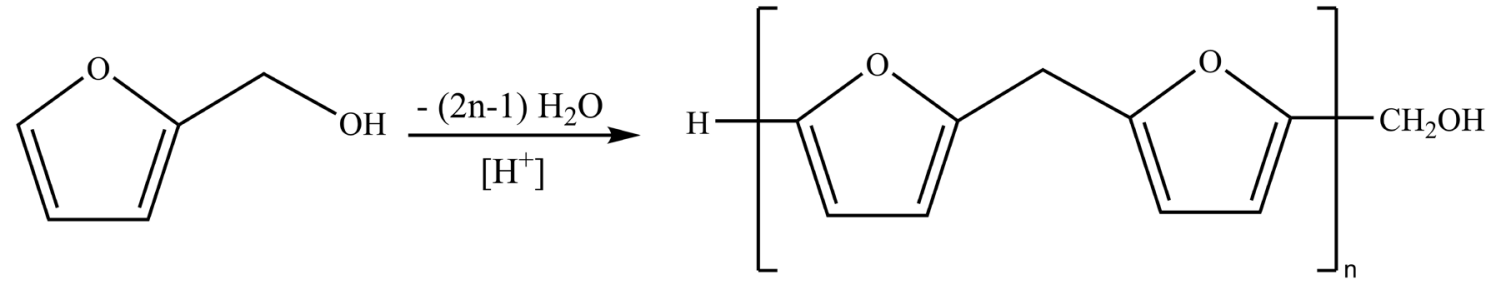

(b)

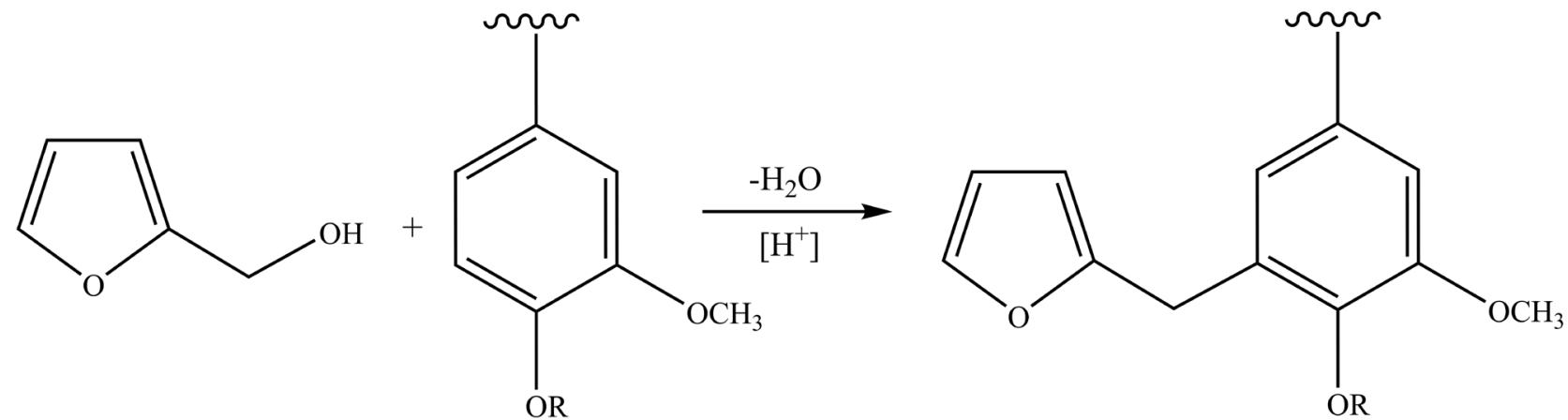

Figure 5: Reactions during the furfurylation of wood: (a) self-condensation of furfuryl alcohol, forming methylene bridge, and (b) condensation of furfuryl alcohol to phenolic compounds via methylene bridging.

Although furfurylated wood products manufactured today are made from Scots pine and radiata pine, several other wood species have been tasked, such as Southern yellow pine, and broad-leaved woods such as maple (Acer spp.), European beech (Fagus sylvatica), and silver birch (Betula pendula) have also been studied (Lande et al., 2004). A summary of furfurylation treatments of selected wood species is given in Table 4. 
Table 4: Overview of the furfurylation of different timber species.

\begin{tabular}{|c|c|c|}
\hline Species & Process condition & Reference \\
\hline $\begin{array}{l}\text { European beech (Fagus sylvatica), European } \\
\text { birch (Betula pendula), Scots pine (Pinus } \\
\text { sylvestris) }\end{array}$ & $\begin{array}{l}\text { Furfuryl alcohol resin (BioRez)/ vacuum for } 45 \text { minutes, } \\
\text { pressure at } 12 \text { bar for } 2 \text { hours. Warming at } 20-40^{\circ} \mathrm{C} \text { for } \\
4 \text { hours, heating at } 103^{\circ} \mathrm{C} \text { for } 16 \text { hours. }\end{array}$ & Lande et al., 2004 \\
\hline Scots pine (sapwood) & Vacuum, 7 - 12 bar, and drying at $130^{\circ} \mathrm{C}$ for 16 hours. & Hoydonckx et al., 2007 \\
\hline $\begin{array}{l}\text { Rubberwood (Hevea brasiliensis), kelempayan } \\
\text { (Neolamarckia cadamba), sena (Pterocarpus } \\
\text { indicus Willd.), European beech, Scots pine } \\
\text { sapwood }\end{array}$ & $\begin{array}{l}\text { Furfuryl alcohol/maleic anhydride or furfuryl alcohol/ } \\
\text { citric acid. Vacuum, } 12 \text { bar, and drying at } 130^{\circ} \mathrm{C} \text { for } 16 \\
\text { hours. }\end{array}$ & Venås and Wong, 2008 \\
\hline $\begin{array}{l}\text { European beech, European ash (Fraxinus } \\
\text { excelsior), radiata pine (Pinus radiata), } \\
\text { Southern yellow pine, Scots pine }\end{array}$ & $\begin{array}{l}\text { Furfuryl alcohol/citric acid, cyclic anhydride, Kebony } \\
\text { process for outdoor level. }\end{array}$ & Puttman et al., 2009 \\
\hline Maritime pine (Pinus pinaster) & $\begin{array}{l}\text { Furfuryl alcohol/additives, vacuum/pressure stage, curing, } \\
\text { vacuum drying. }\end{array}$ & Esteves et al., 2009 \\
\hline $\begin{array}{l}\text { European beech, European ash, radiata pine, } \\
\text { Southern yellow pine }\end{array}$ & $\begin{array}{l}\text { Furfuryl alcohol (30\%), full cell, vacuum drying, steam } \\
\text { cure, drying. }\end{array}$ & Pilgård et al., 2010 \\
\hline Scots pine (sapwood) & $\begin{array}{l}\text { Furfuryl alcohol /citric acid, vacuum, pressure at } 13 \text { bar } \\
\text { for } 2 \text { hours, heating at } 130^{\circ} \mathrm{C} \text { for } 0.5-24 \text { hours. }\end{array}$ & Thygesen et al., 2010 \\
\hline $\begin{array}{l}\text { Chinese white poplar (Populus tomentosa), } \\
\text { Chinese fir (Cunninghamia spp.), swamp } \\
\text { mahogany (Eucalyptus robusta), Masson's pine } \\
\text { (Pinus massoniana) }\end{array}$ & $\begin{array}{l}\text { Furfuryl alcohol/additives vacuum } 30 \text { minutes, } 12 \text { hours } \\
\text { soaking, and } 100^{\circ} \mathrm{C} \text { for } 12 \text { hours. }\end{array}$ & Dong et al., 2016 \\
\hline Masson's pine & $\begin{array}{l}\text { FA/citric acid oxalic acid sodium borate, vacuum, curing at } \\
<115^{\circ} \mathrm{C} \text { for up to } 8 \text { hours, drying } 60-103^{\circ} \mathrm{C} \text {. }\end{array}$ & Li et al., 2016 \\
\hline Scots pine (sapwood) & $40 \%$ furfuryl alcohol (full cell). & Alfredsen et al., 2016 \\
\hline European beech & $\begin{array}{l}\text { Furfuryl alcohol/various catalysts, vacuum for } 5 \text { minutes, } \\
12 \text { bar for } 5 \text { minutes, drying for } 10 \text { hours at } 20^{\circ} \mathrm{C} \text {, heating } \\
<120^{\circ} \mathrm{C} \text { for up to } 24 \text { hours. }\end{array}$ & Sejati et al., 2017 \\
\hline Poplar & $\begin{array}{l}180^{\circ} \mathrm{C} \text { water, furfuryl alcohol } / \text { maleic anhydride, borate, } \\
\text { vacuum for } 1 \text { hour, heating at }<103^{\circ} \mathrm{C} \text { for } 3 \text { hours, then at } \\
60-80^{\circ} \mathrm{C} \text { for } 4 \text { hours, drying at } 103^{\circ} \mathrm{C} \text {. }\end{array}$ & Yang et al., 2019 \\
\hline Radiata pine & $\begin{array}{l}\text { Furfuryl alcohol/additives, soaking for } 15 \text { days, heating at } \\
120^{\circ} \mathrm{C} \text { for } 16.5 \text { hours. }\end{array}$ & Skrede et al., 2019 \\
\hline Southern yellow pine (sapwood) & $\begin{array}{l}\text { Vacuum for } 45 \text { minutes, pressure at } 12 \text { bar for } 2 \text { hours. } \\
\text { warming at } 20-40{ }^{\circ} \mathrm{C} \text { for } 4 \text { hours, heating at } 103^{\circ} \mathrm{C} \text { for } \\
16 \text { hours. }\end{array}$ & Ringman et al., 2020 \\
\hline
\end{tabular}

\subsection{Thermal modification}

The use of heat in wood processing has been important in ensuring its suitability for use for a long time. There are a range of different processes involving the heating of wood:

1. Wood drying

2. Thermal modification

3. Heating in the absence of air, i.e. pyrolysis and thermolysis.

4. Heating in the presence of air, i.e. combustion:

5. Complete combustion with full access to oxygen

6. Incomplete combustion when the availability of oxygen access is limited. 
The processes involving heat and the typical temperature ranges in which they occur and their effects on individual wood components are shown in Figure 6. An elevated temperature is an important component when wood is to be modified solely with the help of water or moisture, but a temperature above $300{ }^{\circ} \mathrm{C}$ is of limited practical value due to the risk of severe degradation of all the main wood constituents, but there are exceptions. The degradation starts or at least becomes identifiable at different temperatures for the different main constituents of wood, the extractives being the most sensitive to a temperature increase due to their lowmolecular nature and low boiling point, followed in turn by hemicelluloses, cellulose, and lignin.

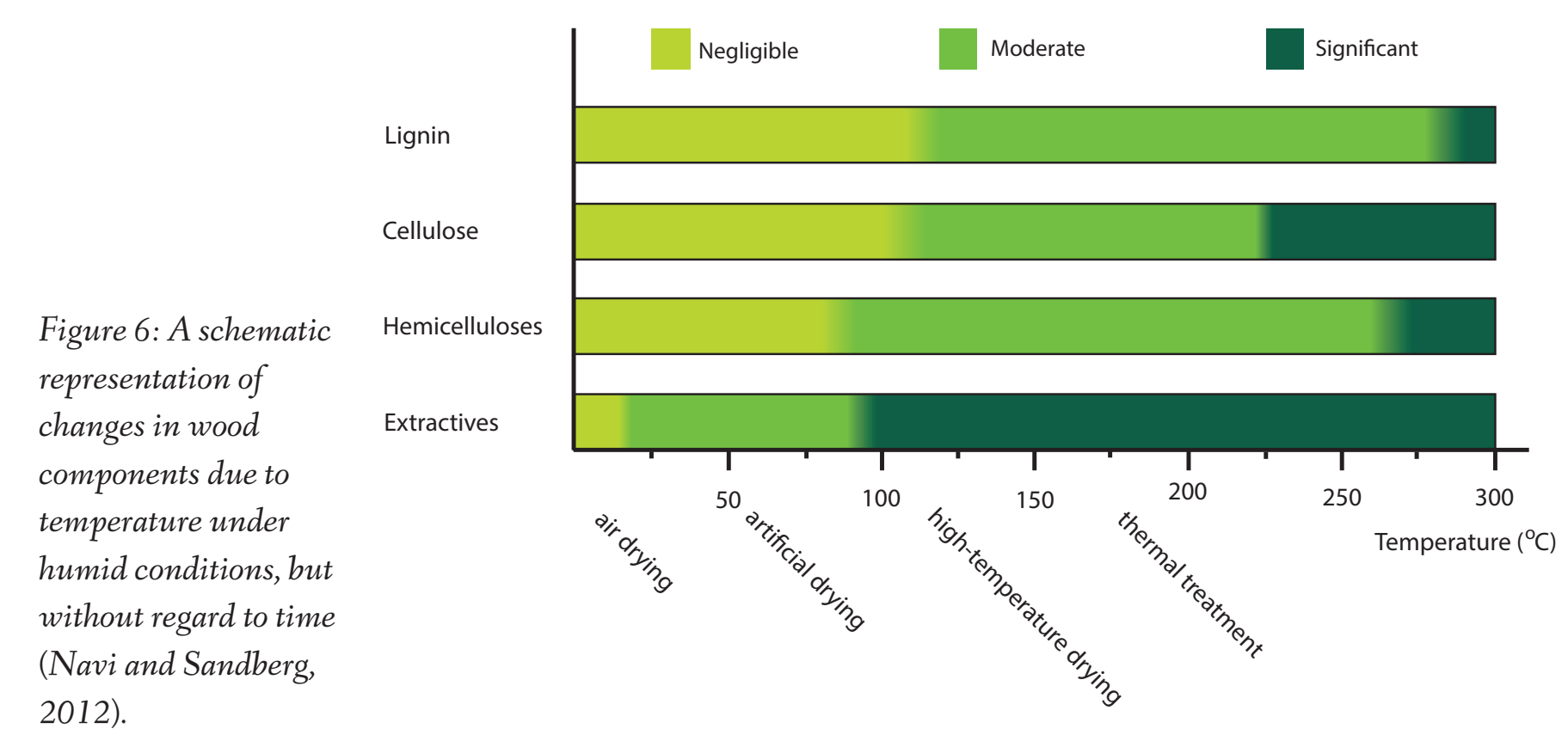

The modification of wood by heat without chemical additives and with a limited supply of oxygen to prevent oxidative combustion, i.e., thermal modification, is a generally accepted and commercialised procedure for improving some characteristics of wood (Jones et al., 2019). The idea is to alter the internal chemical composition of the material by exploiting the internal reactivity of the material and the removal of some of its active sites instead of adding reagents capable of interacting with the reactive sites. The changes in the wood during thermal modification are fairly well understood, involving softening and the redistribution of lignin components, the loss of acid groups and cross-linking and repolymerisation that occur to varying degrees depending on the wood species. The process conditions play a significant role in the chemistry which takes place, hydrolysis and catalysis occurring more in closed system processes.

At temperatures between $160{ }^{\circ} \mathrm{C}$ and $220^{\circ} \mathrm{C}$ (European Committee for Standardization, 2008), the main purpose is to ameliorate material properties, such as to increase the biological durability, to enhance the dimension stability, and also to control the colour changes. Thermal modification has also been applied to reduce resin bleed. The principal effects of heating wood were known already in the early $19^{\text {th }}$ Century. Tredgold (1820) quoted the Encyclopaedia Britannica and states that steaming of wood improves its resistance to white rot, but he referred also to Duhamel du Monceau (1767) stating that steaming and boiling leads to mass loss. Other early examples of wood being thermally modified to improve its resistance to decay are postholes from 
Scandinavian Bronze-age buildings, showing concentrations of charcoal indicating that the ends of the posts had been charred (Källander, 2016).

According to the European Committee for Standardization (2008), thermally modified timber is wood in which the composition of the cell-wall material and its physical properties have been modified by exposure to a temperature higher than $160{ }^{\circ} \mathrm{C}$ with limited access to oxygen. There are various processes to achieve this, mostly differing in the way they exclude air/oxygen from the system (Navi and Sandberg 2012). A steam or nitrogen atmosphere can be used, or the wood can be immersed in hot oil. Among previous reviews dealing with thermal modification are Rapp (2001), Esteves and Pereira (2009), Pelaez-Samaniego et al. (2013), Candelier et al. (2016), Gérardin (2016), and Sandberg et al. (2017). A summary of recent thermal modification studies into different wood species is given in Table 5 .

Table 5: Overview of recent studies into thermal modification.

\begin{tabular}{|c|c|c|c|c|}
\hline Species & Temperature $\left({ }^{\circ} \mathrm{C}\right)$ & $\begin{array}{l}\text { Duration } \\
\text { (hours) }\end{array}$ & Others & Reference \\
\hline $\begin{array}{l}\text { Acacia (Acacia spp.) hybrid } \\
\text { (sapwood) }\end{array}$ & $210-230$ & $2-6$ & Nitrogen & Tuong and Li, 2011 \\
\hline Balkan beech (Fagus moesica C.) & $170,190,210$ & 4 & & Todorović et al., 2015 \\
\hline \multirow{2}{*}{ Bamboo } & 130,180 & 2 or 5 & & Nguyen et al., 2012 \\
\hline & 130,220 & 2 or 5 & & Bremer et al., 2013 \\
\hline Bamboo & $140-200$ & $0.5-2$ & Coconut oil & Manalo and Garcia, 2012 \\
\hline Black pine (Pinus nigra) & $130,180,230$ & 2 or 8 & & Akyildiz and Ates, 2008 \\
\hline Black spruce (Picea mariana) & $190,200,210$ & & & Lekounougou and Kocaefe, 2014 \\
\hline Calabrian pine (Pinus brutia) & $130,180,230$ & 2 or 8 & & $\begin{array}{l}\text { Akyildiz and Ates, 2008; Ates et al., } \\
2009\end{array}$ \\
\hline \multirow{3}{*}{ Common aspen (Populus tremula) } & 195 & & & Wikberg and Maunu, 2004 \\
\hline & $160-170$ & 1 or 3 & $\mathrm{P}=0.65-0.76 \mathrm{MPa}$, steam & Grinins et al., 2013 \\
\hline & 170 & 1 & & Cirule et al., 2016 \\
\hline \multirow{4}{*}{ Common oak (Quercus spp.) } & 160 & & Steam & Wikberg and Maunu, 2004 \\
\hline & $160,180,210,240$ & & & Barcík et al., 2015a,b \\
\hline & $160,180,210$ & 3 & ThermoWood ${ }^{\circledR}$ process & Gaff et al., 2019 \\
\hline & $160,180,210$ & 2 or 3 & ThermoWood ${ }^{\circledR}$ process & Kubovský et al., 2020 \\
\hline European alder (Alnus glutinosa) & $150,180,200$ & 2,6 or 10 & & Yildiz et al., 2011 \\
\hline \multirow{2}{*}{ European ash (Fraxinus excelsior) } & 180,200 & 3 & & Majka and Roszyk, 2018 \\
\hline & 190 & 2.5 & & Cai et al., 2020 \\
\hline \multirow{5}{*}{ European beech (Fagus sylvatica) } & $180,200,220$ & 4 & & Bächle et al., 2010 \\
\hline & 160,190 & & & Boruszewski et al., 2011 \\
\hline & $170,180,190,212$ & 2 & & Kol and Sefil, 2011 \\
\hline & $125-130$ & 6.5 & Steam & Dzurenda, 2013 \\
\hline & 170 & 3 & $\mathrm{P}=0.78 \mathrm{MPa}$ & Altgen et al., 2020a \\
\hline $\begin{array}{l}\text { European white birch (Betula } \\
\text { pendula) }\end{array}$ & 160,190 & & & Boruszewski et al., 2011 \\
\hline \multirow[t]{2}{*}{ Fir (Abies spp.) } & $170,180,190,212$ & 2 & & Kol and Sefil, 2011 \\
\hline & 160,220 & & Vacuum & Allegretti et al., 2012 \\
\hline Fir (Abies spp.) & $\begin{array}{l}100,150,200,220 \\
240,260,280\end{array}$ & 1,3 or 5 & & Kučerová et al., 2019 \\
\hline
\end{tabular}


Table 5 (cont.): Overview of recent studies into thermal modification.

\begin{tabular}{|c|c|c|c|c|}
\hline Species & Temperature $\left({ }^{\circ} \mathrm{C}\right)$ & $\begin{array}{l}\text { Duration } \\
\text { (hours) }\end{array}$ & Others & Reference \\
\hline \multirow[b]{2}{*}{ Flooded gum (Eucalyptus grandis) } & $180,200,220,240$ & 4 or 8 & & de Cademartori et al., 2013a \\
\hline & $140,160,180$ & 45 minutes & VAP Holzsysteme ${ }^{\circledR}$ & $\begin{array}{l}\text { Batista et al., 2015; Carvalho et al., } \\
2019\end{array}$ \\
\hline Grey alder (Alnus incana) & $160-170$ & 1 or 3 & $\mathrm{P}=0.65-0.76 \mathrm{MPa}$, steam & Grinins et al., 2013 \\
\hline $\begin{array}{l}\text { Gympie messmate (Eucalyptus } \\
\text { cloeziana) }\end{array}$ & $180,200,220,240$ & 4 & & de Cademartori et al., 2013b \\
\hline Loblolly pine (Pinus taeda) & $140,160,180$ & 45 minutes & VAP Holzsysteme ${ }^{\circledR}$ & Carvalho et al., 2019 \\
\hline \multirow{2}{*}{$\begin{array}{l}\text { Mantsurian poplar (Populus } \\
\text { cathayaha) }\end{array}$} & $\begin{array}{l}160,180,200,220 \\
240\end{array}$ & 4 & & Wang et al., 2015 \\
\hline & $180-220$ & 4 & & Ling et al., 2016 \\
\hline Maritime pine (Pinus pinaster) & $170-200$ & $2-24$ & & Esteves et al., 2008a \\
\hline Meranti (Shorea spp.) & $160,180,210$ & about 3 & ThermoWood ${ }^{\circledR}$ process & Gašparík et al., 2019 \\
\hline Merbau (Intsia spp.) & $160,180,210$ & about 3 & ThermoWood ${ }^{\circledR}$ process & Ditommaso et al., 2020 \\
\hline $\begin{array}{l}\text { Msasa (Brachystegia spiciformis } \\
\text { Benth.) }\end{array}$ & $215,230,245$ & 2 & Steam & Nhacila et al., 2019 \\
\hline \multirow{2}{*}{$\begin{array}{l}\text { Narrow-leaved ash (Fraxinus } \\
\text { angustifolia) }\end{array}$} & 160,180 & 2 or 4 & & Korkut et al., 2012 \\
\hline & $140,180,200,220$ & 2,4 or 6 & Steam & Yalcin and Sahin, 2015 \\
\hline \multirow{8}{*}{ Norway spruce (Picea abies) } & $160-260$ & $2-8$ & & Kotilainen et al., 2008 \\
\hline & 195 & & & Wikberg and Maunu, 2004 \\
\hline & 200 & $\begin{array}{l}2,4,8,10 \\
\text { or } 24\end{array}$ & $\mathrm{RH}=50,65,80,95 \%$ & Bekhta and Niemz, 2003 \\
\hline & 100,150 & 24 & $\mathrm{RH}=50,65,80,95 \%$ & \\
\hline & 200 & $0.08,0.5$ or 1 & & Follrich et al., 2006 \\
\hline & $180,200,220$ & 4 & & Bächle et al., 2010 \\
\hline & 160,220 & & Vacuum & Allegretti et al., 2012 \\
\hline & $\begin{array}{l}113,134,158,187 \\
221,237,253,271\end{array}$ & 1.5 & & Kačíková et al., 2013 \\
\hline \multirow{2}{*}{ Norway spruce (Picea abies) } & $160,180,210$ & 3 & ThermoWood ${ }^{\circledR}$ process & Gaff et al., 2019 \\
\hline & 180 & 2 & & Cai et al., 2020 \\
\hline $\begin{array}{l}\text { Oil palm (Elaeis guineensis) } \\
\text { mesocarp fibre }\end{array}$ & $190-230$ & 1,2 or 3 & & Nordin et al., 2013 \\
\hline $\begin{array}{l}\text { Oleaster-leafed pear (Pyrus } \\
\text { elaeagrifolia) }\end{array}$ & $160,180,200$ & 3,5 or 7 & & Gunduz et al., 2009 \\
\hline \multirow{2}{*}{ Oriental beech (Fagus orientalis) } & $130,150,180,200$ & 2,6 , or 10 & & Yildiz et al., 2005 \\
\hline & $150,160,170$ & $1,3,5$, or 7 & & Charani et al., 2007 \\
\hline \multirow{2}{*}{ Paulownia spp. } & $160,180,200$ & 3,5 or 7 & & Kaygin et al., 2009 \\
\hline & 150,170 & 0.75 & $\mathrm{P}=0.20$ or $0.225 \mathrm{MPa}$ & Candan et al., 2013 \\
\hline Rubberwood (Hevea brasiliensis) & $210-240$ & $1-8$ & & Srinivas and Pandey, 2012 \\
\hline $\begin{array}{l}\text { Red-bud maple (Acer trautvetteri } \\
\text { Medw.) }\end{array}$ & $120,150,180$ & 2,6 or 10 & & $\begin{array}{l}\text { Korkut et al., 2008a,b; Korkut and } \\
\text { Guller, } 2008\end{array}$ \\
\hline $\begin{array}{l}\text { Red msasa (Brachystegia } \\
\text { spiciformis) }\end{array}$ & $215,230,245$ & 2 & Steam & Nhacila et al., 2019 \\
\hline
\end{tabular}


Table 5 (cont.): Overview of recent studies into thermal modification.

\begin{tabular}{|c|c|c|c|c|}
\hline Species & Temperature $\left({ }^{\circ} \mathrm{C}\right)$ & $\begin{array}{l}\text { Duration } \\
\text { (hours) }\end{array}$ & Others & Reference \\
\hline \multirow{8}{*}{ Scots pine (Pinus sylvestris) } & 160 & 5 & 0.6 & Burmester, 1973 \\
\hline & $160-260$ & $2-8$ & & Kotilainen et al., 2008 \\
\hline & $120,150,180$ & 2,6 or 10 & & Korkut et al., 2008a,b \\
\hline & $180,200,240$ & & & Kekkonen et al., 2010 \\
\hline & $160,180,210,240$ & & & Barcík et al., 2015a \\
\hline & $125,140,155,170$ & 3 & $\begin{array}{l}\text { Superheated steam at } \\
\text { atmospheric pressure }\end{array}$ & Altgen et al., 2020b \\
\hline & 180 & 2 & & Cai et al., 2020 \\
\hline & 225 & 3 & & Willems et al., 2020 \\
\hline \multirow{2}{*}{ Sessile oak (Quercus petraea) } & $130,180,230$ & 2 or 8 & & Akyildiz and Ates, 2008 \\
\hline & 190,212 & $1-2$ & ThermoWood ${ }^{\circledR}$ process & Gurleyen et al., 2019 \\
\hline \multirow{2}{*}{ Silver oak (Grevillea robusta) } & $210-240$ & $1-8$ & & Srinivas and Pandey, 2012 \\
\hline & $185-230$ & $2-3$ & & Sikora et al., 2018 \\
\hline Small-leaved lime (Tilia cordata) & 140 & up to 504 & $\mathrm{RH}=10 \%$ & $\begin{array}{l}\text { Popescu et al., 2013a,b; Popescu and } \\
\text { Popescu, } 2013\end{array}$ \\
\hline \multirow{2}{*}{ Sweet chestnut (Castanea sativa) } & $130,180,230$ & 2 or 8 & & Akyildiz and Ates, 2008 \\
\hline & 160,180 & 2 or 4 & & Korkut et al., 2012 \\
\hline Teak (Tectona grandis) & $160,180,210$ & about 3 & ThermoWood ${ }^{\circledR}$ process & Gašparík et al., 2019 \\
\hline Turkish hazel (Corylus colurna) & $120,150,180$ & 2,6 or 10 & & Korkut and Hiziroglu, 2009 \\
\hline \multirow{4}{*}{ Warty birch (Betula pendula) } & 195 & & & Wikberg and Maunu, 2004 \\
\hline & $140,160,180$ & 1 & & Biziks et al., 2013 \\
\hline & $160-170$ & 1 or 3 & $\mathrm{P}=0.65-0.76 \mathrm{MPa}$, steam & Grinins et al., 2013 \\
\hline & $160,180,210,240$ & & & Barcík et al., 2015a \\
\hline Western red cedar (Thuja plicata) & 220 & 1 or 2 & & Awoyemi and Jones, 2011 \\
\hline
\end{tabular}

\subsection{Impregnation polymerisation}

The use of resins for improving the properties of wood is a well-studied procedure, with the development of the Impreg ${ }^{\mathrm{TM}}$ and Compreg ${ }^{\mathrm{TM}}$ processes during the first half of the $20^{\text {th }}$ Century (Stamm and Seborg, 1943, 1944; Stamm et al., 1946). As the name suggests, the main difference between Impreg ${ }^{\mathrm{TM}}$ and Compreg ${ }^{\mathrm{TM}}$ is the application of compressive forces before and during the curing process of the latter. An excellent overview of properties of these two products was given by Ibach (2010), which is summarised in Table 6.

Table 6: Comparison of Impreg ${ }^{\mathrm{TM}}$ and Compreg ${ }^{\mathrm{TM}}$ processed timbers (Ibach, 2010).

\begin{tabular}{|c|c|c|}
\hline Property & Impreg $^{\mathrm{TM}}$ & Compreg $^{\mathrm{TM}}$ \\
\hline Density & $15 \%$ to $20 \%$ greater than untreated wood & Usually 1,000 to $1,400 \mathrm{~kg} / \mathrm{m}^{3}$ \\
\hline Equilibrium swelling and shrinking & $1 / 4$ to $1 / 3$ that of untreated wood & $\begin{array}{l}1 / 4 \text { to } 1 / 3 \text { that of untreated wood at right angle to } \\
\text { direction of compression, greater in direction of } \\
\text { compression but very slow to attain }\end{array}$ \\
\hline Spring-back & None & Very small when properly made \\
\hline Face checking & Practically eliminated & $\begin{array}{l}\text { Practically eliminated for densities less than } \\
1,300 \mathrm{~kg} / \mathrm{m}^{3}\end{array}$ \\
\hline Grain raising & Greatly reduced & $\begin{array}{l}\text { Greatly reduced for uniform-texture woods, } \\
\text { considerable for contrasting grain woods }\end{array}$ \\
\hline
\end{tabular}


Table 6 (cont.): Comparison of Impreg ${ }^{\mathrm{TM}}$ and Compreg $^{\mathrm{TM}}$ processed timbers (Ibach, 2010).

\begin{tabular}{|c|c|c|}
\hline Property & Impreg $^{\mathrm{TM}}$ & Compreg $^{\mathrm{TM}}$ \\
\hline Surface finish & Similar to untreated wood & $\begin{array}{l}\text { Varnished-like appearance for densities greater } \\
\text { than } 1,000 \mathrm{~kg} / \mathrm{m}^{3} \text {; cut surfaces can be given this } \\
\text { surface by sanding and buffing }\end{array}$ \\
\hline Permeability to water vapour & About $1 / 10$ that of untreated wood & $\begin{array}{l}\text { No data, but presumably much less than } \\
\text { Impreg }^{\text {TM }}\end{array}$ \\
\hline Decay and termite resistance & Considerably better than untreated wood & Considerably better than untreated wood \\
\hline Acid resistance & Considerably better than untreated wood & $\begin{array}{l}\text { Better than Impreg } \\
\text { impermeability }\end{array}$ \\
\hline Alkali resistance & Same as untreated wood & $\begin{array}{l}\text { Somewhat better than untreated wood because } \\
\text { of impermeability }\end{array}$ \\
\hline Fire resistance & Same as untreated wood & $\begin{array}{l}\text { Same as untreated wood for long exposures, } \\
\text { somewhat better for short exposures }\end{array}$ \\
\hline Heat resistance & Greatly increased & Greatly increased \\
\hline Electrical conductivity & $\begin{array}{l}\text { conductivity } 1 / 10 \text { that of untreated wood at } 30 \% \\
\mathrm{RH} ; 1 / 1,000 \text { that of untreated wood at } 90 \% \mathrm{RH}\end{array}$ & $\begin{array}{l}\text { Slightly more than Impreg } \\
\text { humidity values due to entrapped water }\end{array}$ \\
\hline Heat conductivity & Slightly increased & $\begin{array}{l}\text { Increased about in proportion to specific } \\
\text { gravity increase }\end{array}$ \\
\hline Compressive strength & $\begin{array}{l}\text { Increased more than proportional to specific } \\
\text { gravity increase }\end{array}$ & $\begin{array}{l}\text { Increased considerably more than proportional } \\
\text { to specific gravity increase }\end{array}$ \\
\hline Tensile strength & Decreased significantly & $\begin{array}{l}\text { Increased less than proportional to specific } \\
\text { gravity increase }\end{array}$ \\
\hline Flexural strength & $\begin{array}{l}\text { Increased less than proportional to specific } \\
\text { gravity increase }\end{array}$ & $\begin{array}{l}\text { Increased less than proportional to specific } \\
\text { gravity increase parallel to grain, increased } \\
\text { more perpendicular to grain }\end{array}$ \\
\hline Hardness & $\begin{array}{l}\text { Increased considerably more than proportional } \\
\text { to specific gravity increase }\end{array}$ & 10 to 20 times that of untreated wood \\
\hline $\begin{array}{l}\text { Impact strength } \\
\text { - Toughness } \\
\text { - Izod }\end{array}$ & $\begin{array}{l}\text { - About } 1 / 2 \text { of value for untreated wood, but } \\
\text { very susceptible to the variables of manufacture } \\
\text { - About } 1 / 5 \text { of value for untreated wood }\end{array}$ & $\begin{array}{l}-1 / 2 \text { to } 3 / 4 \text { of value for untreated wood, but very } \\
\text { susceptible to the variables of manufacture } \\
\cdot 1 / 3 \text { to } 3 / 4 \text { of value for untreated wood }\end{array}$ \\
\hline Abrasion resistance (tangential) & About $1 / 2$ of value for untreated wood & $\begin{array}{l}\text { Increased about in proportion to specific } \\
\text { gravity increase }\end{array}$ \\
\hline Machinability & $\begin{array}{l}\text { Cuts cleaner than untreated wood, but dulls } \\
\text { tools more }\end{array}$ & $\begin{array}{l}\text { Requires metalworking tools and metalworking } \\
\text { tool speeds }\end{array}$ \\
\hline Mouldability & $\begin{array}{l}\text { Cannot be moulded but can be formed to single } \\
\text { curvatures at time of assembly }\end{array}$ & $\begin{array}{l}\text { Can be moulded by compression and } \\
\text { expansion moulding methods }\end{array}$ \\
\hline Glueability & Same as untreated wood & $\begin{array}{l}\text { Same as untreated wood after light sanding or } \\
\text { in the case of thick stock, machining surfaces } \\
\text { plane }\end{array}$ \\
\hline
\end{tabular}

Typically, Compreg ${ }^{\mathrm{TM}}$ is based on phenol-formaldehyde resins, whilst Impreg ${ }^{\mathrm{TM}}$ can be based on phenol-, melamine- or urea-based, cured under mild acidic or alkaline conditions, and incorporating a monomer such as methyl methacrylate or styrene, which provide hardening by a stepwise polymerisation mechanism. An overview of the resin modification of wood was reported by Stefanowski et al. (2018).

In addition to the development of Compreg-type products, there have been a range of Impreg-type products manufactured. The commercial production of wood treated with poly(methyl methacrylate) has been carried out since the 1950s. The US company Gammapar commercialised the production of acrylic impregnated parquet flooring in 1963. Grammapar was taken over in 2001 by Nydree, who subsequently in 2003 took over the 
product PermaGrain ${ }^{\circledR}$. Nydree flooring is still sold as an acrylic infused wood is made with superior toughness over untreated products.

The Indurite ${ }^{\mathrm{TM}}$ technology was started indirectly via Scion's Indurite ${ }^{\mathrm{TM}}$ development from 1985 to 1988, when a new strategy for wood modification was devised. Patents were granted for the process (Franich and Anderson, 1998), and the Indurite ${ }^{\mathrm{TM}}$ technology was scaled-up by the Engineered Wood Solutions company in New Zealand, after which it was obtained by the Osmose company (Franich, 2007). A more traditional resin is now used, the material being produced under a new product brand, Lignia ${ }^{\circledR}$ in the United Kingdom.

Another impregnation/polymerisation process that has gained commercial interest in recent years is the use of 1,3-dimethylol-4,5-dihydroxyethyleneurea (DMDHEU) that was used in the early version of the Belmadur process operated by BASF between 2010 and 2016. This is an example of treatment that has been used in other industrial areas; in this case as an anti-wrinkling agent in cellulose and cellulose-blended fabrics (Schindler and Hauser, 2004). The use of DMDHEU has recently been reviewed (Emmerich et al., 2019). The production of Belmadur ${ }^{\circledast}$ using DMDHEU was stopped in 2016, but Archroma Management GmbH (Reinach, Switzerland) together with the University in Göttingen, Germany, have now resumed investigations to improve the technology using DMDHEU (Emmerich, 2016). Recently, another cross-linking agent (glyoxal) has been advertised by BASF in a process named Belmadur ${ }^{\oplus}$ (BASF 2020). Radiata pine is the preferred species due to the cooperation between TimTechChem International Ltd in Auckland, New Zealand (Emmerich et al., 2019).

\section{Wood Modification in Europe}

As part of the work in the COST FP1407 Action, it was decided to determine the levels of wood modification across Europe. From earlier work (Militz, 2015), the degrees of commercialisation were reported, as shown in Table 7.

Table 7: Market position of different wood modification methods (Militz, 2015).

\begin{tabular}{lll}
\hline On the market / commercial production & Ready to be commercialised & Still at research phase \\
\hline Thermal modification & & \\
Acetylation & Chitosan/lignin/tannin \\
Furfurylation & DMDHEU & Extractives \\
Silicone/silane/water glass & & Other chemicals \\
Phenolic resin & \\
Oils/waxes/paraffins & \\
\hline
\end{tabular}

An evaluation of the scientific literature (Jones et al., 2019) showed that levels of interest in wood modification were increasing, based on researchers, policy makers and end-users becoming more aware of the importance of the bioeconomy in our future and the need for more environmentally-acceptable treatments. As a result of the activities within COST FP1407 and subsequent overview of all European countries, it was possible to determine more realistic production rates for modified wood, and a better differentiation of modification types on the market, as shown in Table 8 (Jones et al., 2019).

Given that the global production volume from the ThermoWood Association was reported to be 193,700 $\mathrm{m}^{3}$ in 2017 (International ThermoWood Association, 2018), demonstrating how other groups across Europe have expanded into the production of thermally modified timber. This has been aided by the development of small 
Table 8: Summary of production levels in Europe (including anticipated production from new capacities).

\begin{tabular}{lr}
\hline Type of wood modification & Estimated annual production $\left(\mathrm{m}^{3}\right)$ \\
\hline Thermally modified timber incl. aged timber & 535,000 \\
Densified wood & 2,000 \\
Acetylated timber incl. production under development in UK & 120,000 \\
Furfurylated timber incl. production under development in Belgium & 45,000 \\
Other chemical methods & 35,000 \\
\hline
\end{tabular}

thermal treatment kilns, such as those produced by IVSE in Italy and Jartek in Finland, with the latter having manufactured more than 50 thermal modification kilns for use globally. Indeed, the national production of thermally modified timber was reported by 27 of the 31 countries that responded to the European questionnaire (Jones et al., 2019). Since the publication of this data, it has been noted that there appears to be an additional $160,000 \mathrm{~m}^{3}$ of thermally modified timber produced by Thermory ${ }^{\oplus}$ in Estonia, demonstrating the regular increases in production levels. Thus, the European production levels of thermally modified timber should be $695,000 \mathrm{~m}^{3}$. The popularity of thermal modification, particularly through its ability to be commercialised on small scales suited to local production facilities, was borne out by the number of European counties reporting some degree of commercial production (Figure 7).

Figure 7: Production of thermally modified wood in Europe. Red $=$ Production volumes over 10,000 $m^{3} /$ year,

Orange $=$ Production volumes under 10,000 $\mathrm{m}^{3} /$ year,

Green $=$ no reported production volumes, Grey $=$ No data available.

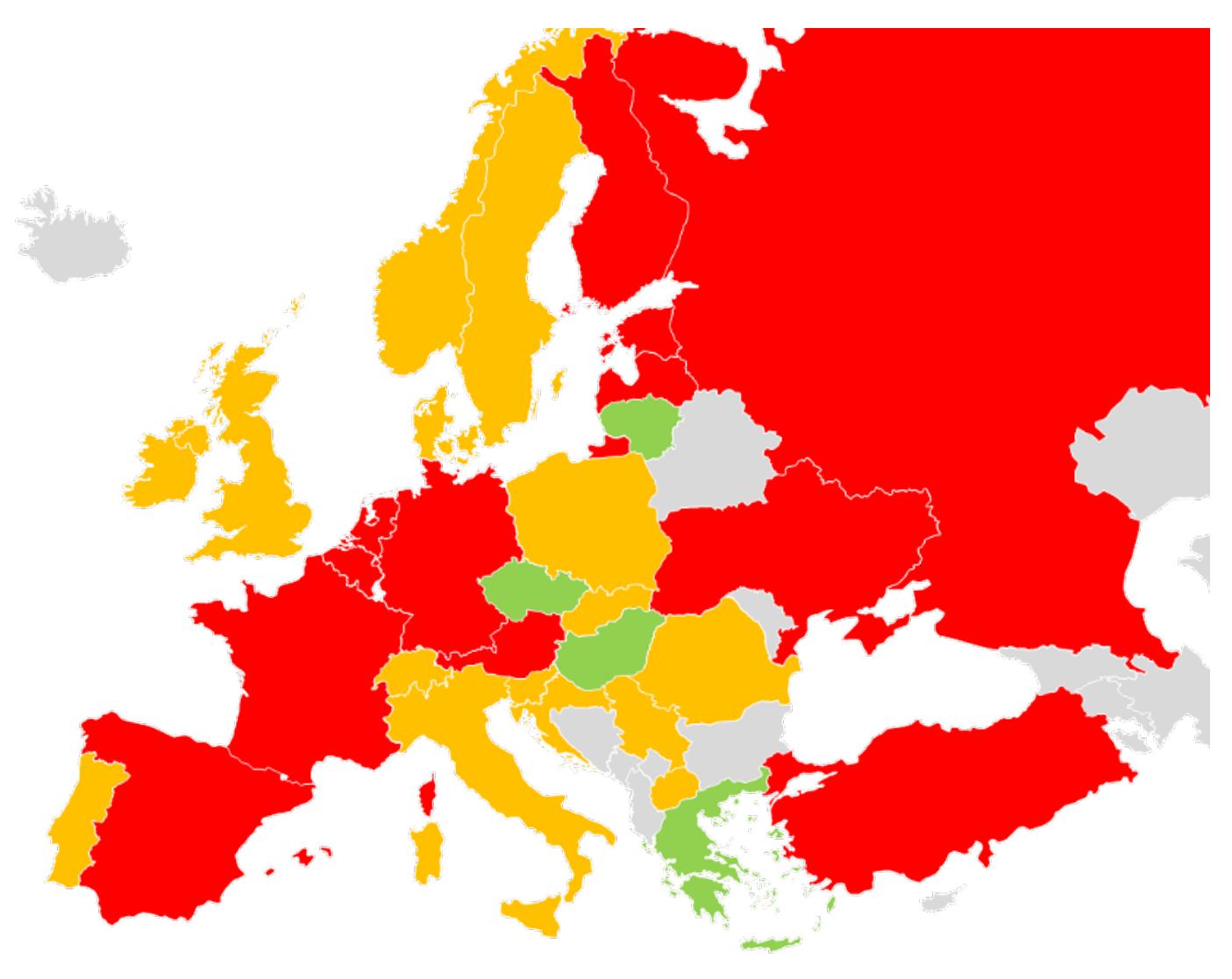




\section{Global Wood Modification Position}

It is recognised that the European Union has led the development of wood modification in recent years, but opportunities for many of these technologies exist globally, given that the aim of most treatments has been the upgrading of fast-grown (local) softwood species. Indeed, the acetylation (Accoya ${ }^{\oplus}$ ) process has to date been based on the use of radiata pine, due to its uniformity and ease of treating. Similarly, species such as poplar and Southern yellow pine have been extensively studies with various modification methods. To date, acetylation and furfurylation remain as European commercial entities, though Eastman Chemicals explored opportunities for the acetylation of Southern yellow pine in the commercial production of Perennial Wood ${ }^{\text {TM }}$, though this has ceased production for the current time.

As demonstrated with the European market, it is thermal modification that has been most widely developed globally, again based on the ease of construction of treatment kilns suited to a wide range of production levels. Currently there are several companies in China producing thermally modified timber from species such as Dahurian larch (Larix gmelinii (Rupr.)), Pará rubber tree (Havea brasiliensis), and Shiny xylosma (Xylosma congestum) as well as plantation-grown poplar spp. and Chinese fir. 2018 estimates indicate there to be a production of around 250,000 cubic metres per year, of which 200,000 cubic metres is classified as a light treatment (from operating temperatures of 140 to $180^{\circ} \mathrm{C}$ ), with the remainder classified as deep treatment (temperatures used between 180 and $220^{\circ} \mathrm{C}$ ).

In terms of production levels, the other area where thermal modification has become commercialised to a significant level is in North America. As reported by Espinoza et al. (2015), the estimated production levels of thermally modified timber for 2012 was 100,000 $\mathrm{m}^{3}$. Given the size of the U.S. / North American timber market, this represents a very slow uptake of a new treatment technology suited to upgrading locally grown pine species and historically a result of research and development originating in the U.S. Many of the reasons for this were explained by Morrell (2018), including issues over marketing and product conformity. The need to standardise thermally modified timber within the American codes and standards was recognised through the drafting of a document for the American Wood Preservation Association (AWPA) to overcome the lack of technical data available to specifiers and end-users (Donahue and Winandy, 2014). In Canada, the majority of thermal modification is linked to collaboration with the International ThermoWood Association, particularly through ThermoWood ${ }^{\oplus}$ Canada and Scottywood ${ }^{\mathrm{TM}}$ Canada. It is assumed that these two groups account for the majority of the foreign (non-European) production of ThermoWood ${ }^{\oplus}$, which is estimated at over $30,500 \mathrm{~m}^{3}$ for all non-European countries (17\% of the total global production, Sandberg et al. 2017). Overall, there were several producers of thermally modified wood in Canada and ten in the U.S. in 2012 (Sandberg and Kutnar, 2016).

Thermal modification is not well established in other parts of the globe, with countries such as Australia and South Africa more dependent on preservative treated timber and imported modified timber from current producers in Europe and Asia. New Zealand has some production of thermally modified timber, based on the treatment of locally grown radiata pine. One company, Donelley Sawmillers Ltd, recently doubled its production capacity in 2019 upon the delivery of a second Jartek treatment chamber of $35 \mathrm{~m}^{3}$. In 2017, Abodo expanded its production of thermally modified timber under its trade name Vulcan ${ }^{\mathrm{TM}}$ cladding by a further $8,000 \mathrm{~m}^{3}$ a year, whilst Tunnicliffe's Timber produce ThermoWood ${ }^{\oplus}$ radiata pine, but at an elevated temperature of $230{ }^{\circ} \mathrm{C}$. Thermally modified hardwood timber, under the tradename Truwood ${ }^{\mathrm{TM}}$ has been imported into New Zealand by Rosenfeld Kitson for several cladding projects. 
As a result of several studies (Batista, 2016, 2018), two commercial facilities have been established in Brazil. Whilst one has only just started production in 2019, the other company (Vale do Cedro - Cedar Valley), produces just over $5,300 \mathrm{~m}^{3}$ per year from plantation species such as Acrocarpus fraxinifolius, Toona ciliata, Pinus spp., and Tectona grandis.

Another modification process that has been commercialised globally is the resin impregnation/polymerisation process. In China, this has been undertaken on a range of resin systems, including low molecular weight ureaformaldehyde (UF) resin, phenolic resins and wax. The modification with furfuryl alcohol is also included in the various resin systems being used and it is uncertain if this is using a system similar to the furfurylation processes undertaken in Europe. Hence no attempt has been made to separate production volumes using furfuryl alcohol from other resin systems. Overall, there is a total production of resin impregnated wood in China of $290,000 \mathrm{~m}^{3}$ by six companies, whilst there is the production capacity to more than double this volume should market demands arise. It is known that phenolic resins have been commercially applied to low-density hardwoods in several Asian countries (e.g., Malaysia, India) to produce Compreg ${ }^{\text {TM }}$ plywood products. Thus, species such as sesandok (Endospermum diadenum), jelutong (Dyera costulata), rubberwood (Hevea brasiliensis), and mahang (Macaranga spp.) among many others have been used to manufacture high-performance products.

Finally, the modification of wood with DMDHEU was previously undertaken in Europe by the BASF Group under the name Belmadur ${ }^{\oplus}$ in the early 2000s. The process has since been licensed to TimTech company in New Zealand, who are developing commercial production under the new tradename HartHolz ${ }^{\mathrm{TM}}$.

\section{Marketing of Modified Wood}

The performance of modified wood in various product applications is defined by the Durability Class which the treatment confers on the treated wood and the Use Class as defined by EN 335 (European Committee for Standardization, 2013). A specification manual by the Wood Protection Association in the United Kingdom (WPA, 2011) categorised various product ranges according to typical Use Classes, as shown in Table 1. Based on these definitions, the categorisation of key product groups (WPA, 2011) were proposed. These have been modified herein, comprising the groups as shown in Table 9.

Table 9: Product groups and their associated Use Classes (modified from WPA 2012).

\begin{tabular}{|c|c|c|c|c|}
\hline Group & Identifier & Use Classes & & \\
\hline & Indoor furniture & $\begin{array}{c}\text { UC } \\
1\end{array}$ & & \\
\hline & Floor and non-structural interior uses & $\begin{array}{cc}\mathrm{UC} \\
1\end{array}$ & & \\
\hline & Exterior joinery & & $\begin{array}{c}\text { UC } \\
3.1\end{array}$ & $\begin{array}{l}\text { UC } \\
3.2\end{array}$ \\
\hline & Cladding & & $\begin{array}{l}\text { UC } \\
3.1\end{array}$ & $\begin{array}{l}\text { UC } \\
3.2\end{array}$ \\
\hline & Decking & & $\begin{array}{l}\text { UC } \\
3.1 \\
\end{array}$ & $\begin{array}{l}\text { UC } \\
3.2\end{array}$ \\
\hline & Fencing & & $\begin{array}{l}\text { UC } \\
3.1\end{array}$ & $\begin{array}{l}\text { UC } \\
3.2\end{array}$ \\
\hline
\end{tabular}


Table 9 (cont.): Product groups and their associated Use Classes (modified from WPA 2012).

\begin{tabular}{|c|c|c|c|c|c|c|}
\hline Group & Identifier & Use Classes & & & & \\
\hline & Outdoor furniture & & $\begin{array}{c}U C \\
3.1\end{array}$ & $\begin{array}{l}\text { UC } \\
3.2\end{array}$ & $\begin{array}{c}\text { UC } \\
4\end{array}$ & \\
\hline & Construction elements & & $\begin{array}{l}U C \\
3.1\end{array}$ & $\begin{array}{l}\text { UC } \\
3.2\end{array}$ & $\begin{array}{c}\text { UC } \\
4\end{array}$ & \\
\hline & In-ground timber & & & & $\begin{array}{c}\text { UC } \\
4\end{array}$ & \\
\hline & Products exposed to water & & & & $\begin{array}{c}\text { UC } \\
4\end{array}$ & $\begin{array}{c}\text { UC } \\
5\end{array}$ \\
\hline
\end{tabular}

\section{Overview and Conclusion}

Table 10 gives an estimated overview of the global production of modified wood. Since the production levels of Compreg ${ }^{\mathrm{TM}}$ plywood is uncertain at this given time, this has not been added to this table. Similarly, the production volumes of resin impregnated wood in China may incorporate Compreg-type products, thus the actual modification of solid wood may be considerably lower in this case. Another form of treatment, shou sugi ban (the charring of wooden surfaces) has not been included in this study, though its increasing popularity with architects is recognised.

Table 10: Overall estimated global production of modified wood.

\begin{tabular}{|c|c|c|c|c|c|}
\hline \multirow[t]{2}{*}{ Modification } & \multicolumn{5}{|c|}{ Estimated volumes $\left(\mathrm{m}^{3}\right)$} \\
\hline & Europe & China & N. America & Oceania/Japan & Other \\
\hline Thermally modified timber & $695,000^{*}$ & 250,000 & 140,000 & 15,000 & 10,000 \\
\hline Densified wood & 2,000 & $<1,000$ & & $<1,000$ & \\
\hline Acetylation & 120,000 & & & & \\
\hline Furfurylation & 45,000 & & & & \\
\hline Other methods & 35,000 & $290,000^{* *}$ & & 5,000 & $\mathrm{TBD}^{* *}$ \\
\hline
\end{tabular}

* Value adjusted from that in Table 1 (Jones et al. 2019) based on additional data from Estonia.

** Figures are a combination of furfurylation processes other than Kebony ${ }^{\circledR}$ and Nobelwood ${ }^{\circledR}$, as well as DMDHEU and other resin treatments.

Based on the information within Table 10, it would appear there is a global production volume of $1,608,000 \mathrm{~m}^{3}$ per year, which is dominated by thermal modification. Further increase in production is predicted in the coming years based on consumer needs, licensing of technologies and the relative ease of production of thermally modified timber using stand-alone treatment chambers.

In terms of the application of modified wood, surveys and overviews undertaken by the authors herein indicate that various wood modification treatments can be applied the Use Classes as described in Table 11. The Use Classes where the modified wood products have been commercially demonstrated are marked in green, whilst those in yellow refer to those where studies indicate products may be used. 
Table 11: Application of different wood modification methods into products in different Use Classes.

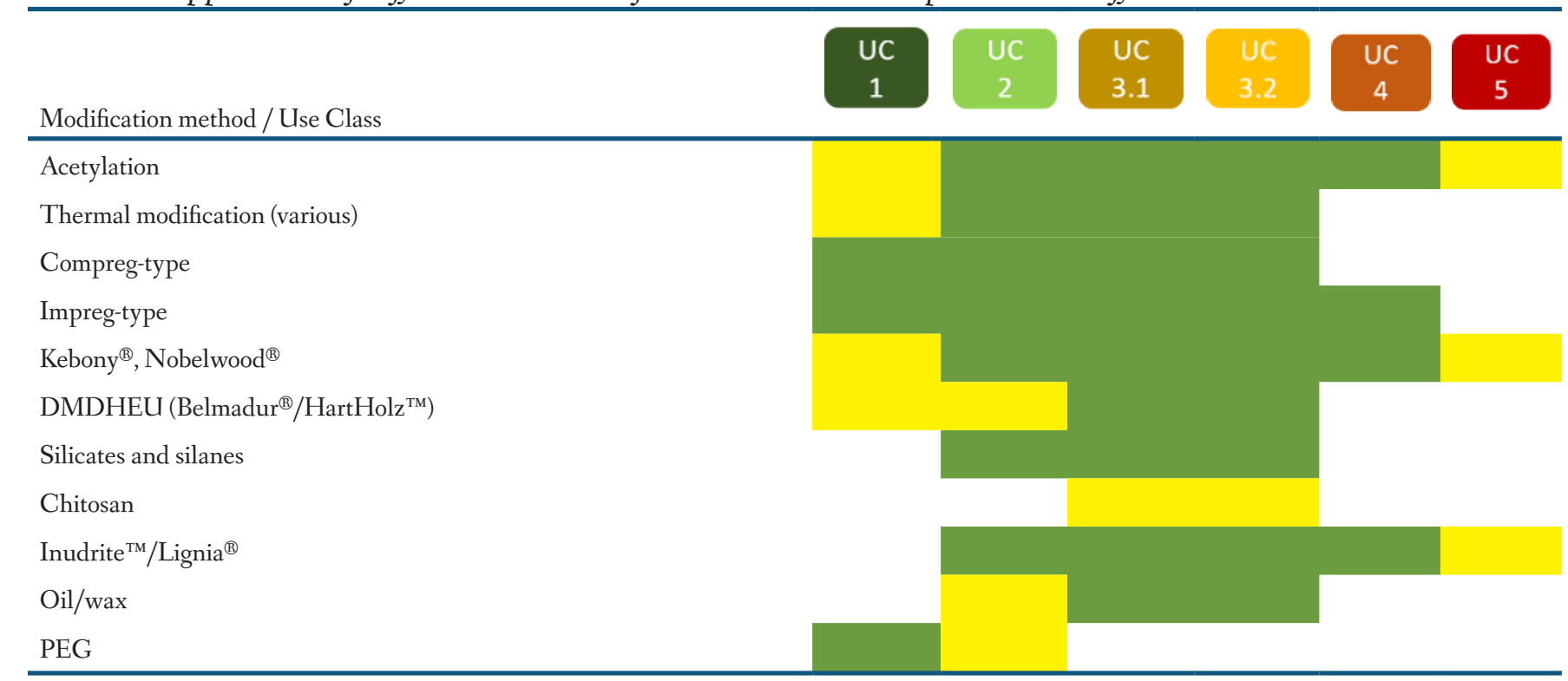

Furthermore, the various modification methods are summarised in Table 12, along with their technology readiness levels (TRLs). The TRL is a defined scale of the degree of commercialisation that has been achieved, where 1 describes an unproven basic concept still to be attempted at the laboratory scale, and 9 is full commercial production. It can be seen from Table 12 that several of the wood modification methods have achieved full commercial production, whilst others (such as the HartHolz ${ }^{\mathrm{TM}}$ and Lignia ${ }^{\oplus}$ processes) are commercial realities but not in full production.

Table 12: Summary of chemical modification processes and typically used wood species, process parameters, properties and Technology Readiness Level (TRL). T and P are process temperature and pressure, respectively.

\begin{tabular}{|c|c|c|c|c|}
\hline Process & Species used & Process parameters & Properties of the modified wood & $\begin{array}{l}\text { TRL } \\
\text { scale* }^{*}\end{array}$ \\
\hline Accoya ${ }^{\circledR}$ & Radiata pine & $\begin{array}{l}\mathrm{T}:<170{ }^{\circ} \mathrm{C} \\
\mathrm{P}: \text { pressurised } 2.2 \mathrm{MPa}\end{array}$ & $\begin{array}{l}\text { Improved dimensional stability, } \\
\text { durability, low mould resistance, } \\
\text { corrosive to fastener }\end{array}$ & 9 \\
\hline Thermal modification (various) & $\begin{array}{l}\text { Norway spruce, Scots pine, } \\
\text { various }\end{array}$ & $\begin{array}{l}\mathrm{T}: 160-230^{\circ} \mathrm{C} \\
\mathrm{P}: \text { various }\end{array}$ & $\begin{array}{l}\text { Improved dimensional stability, } \\
\text { moderate durability, reduced } \\
\text { mechanical properties }\end{array}$ & 9 \\
\hline Compreg $^{\mathrm{TM}}$ (various) & European beech (veneer) & $\begin{array}{l}\mathrm{T}: 125-150^{\circ} \mathrm{C} \\
\text { P: } 7 \mathrm{MPa}\end{array}$ & $\begin{array}{l}\text { Improved strength (hardness), } \\
\text { durability permeability, electric } \\
\text { resistance etc., high density }\end{array}$ & 9 \\
\hline Kebony ${ }^{\circledR}$, Nobelwood ${ }^{\circledR}$ & Radiata pine, Scots pine & $\begin{array}{l}\mathrm{T}:<140^{\circ} \mathrm{C} \\
\mathrm{P}:<1.2 \mathrm{MPa}\end{array}$ & $\begin{array}{l}\text { Improved durability, dimensional } \\
\text { stability, hardness, corrosion to } \\
\text { fasteners, lower toughness }\end{array}$ & 9 \\
\hline DMDHEU (HartHolz ${ }^{\mathrm{TM}}$ ) & $\begin{array}{l}\text { European beech, Scots } \\
\text { pine }\end{array}$ & $\begin{array}{l}\mathrm{T}:>100^{\circ} \mathrm{C} \\
\mathrm{P}: 1.2 \mathrm{MPa}\end{array}$ & Improved durability & 8 \\
\hline Organowood ${ }^{\circledR}$ & Norway spruce, Scots pine & $\begin{array}{l}\mathrm{T}: 20-120^{\circ} \mathrm{C} \\
\text { P: low } 1.6 \mathrm{MPa}\end{array}$ & $\begin{array}{l}\text { Stable silver-grey surface, improved } \\
\text { durability }\end{array}$ & 9 \\
\hline Impreg $^{\mathrm{TM}}(\mathrm{MF})$ (various) & $\begin{array}{l}\text { European beech, Scots } \\
\text { pine }\end{array}$ & $\begin{array}{l}\mathrm{T}: 60-150{ }^{\circ} \mathrm{C} \\
\mathrm{P}: 0.005-1.2 \mathrm{MPa}\end{array}$ & $\begin{array}{l}\text { Improved durability, less swelling/ } \\
\text { shrinking, lower hardness and } \\
\text { toughness }\end{array}$ & 7 \\
\hline
\end{tabular}


Table 12 (cont.): Summary of chemical modification processes and typically used wood species, process parameters, properties and Technology Readiness Level (TRL). T and P are process temperature and pressure, respectively.

\begin{tabular}{|c|c|c|c|c|}
\hline Process & Species used & Process parameters & Properties of the modified wood & $\begin{array}{l}\text { TRL } \\
\text { scale }^{*}\end{array}$ \\
\hline Chitosan & $\begin{array}{l}\text { European beech, Scots } \\
\text { pine }\end{array}$ & $\begin{array}{l}\mathrm{T}: 20-80^{\circ} \mathrm{C} \\
\mathrm{P}: 0.01-1.2 \mathrm{MPa}\end{array}$ & Improved durability & 2 \\
\hline Indurite $^{\mathrm{TM}}$, Lignia ${ }^{\circledR}$ & Radiata pine & $\begin{array}{l}\mathrm{T}: 70^{\circ} \mathrm{C} \\
\mathrm{P}: 0.015-1.4 \mathrm{MPa}\end{array}$ & Improved stability and durability & 8 \\
\hline Linotech $^{\mathrm{TM}}$ & $\begin{array}{l}\text { Scots pine, (Norway } \\
\text { spruce) }\end{array}$ & $\begin{array}{l}\mathrm{T}: 60-140{ }^{\circ} \mathrm{C} \\
\text { P: } 0.8-1.4 \mathrm{MPa}\end{array}$ & Improved durability, oil exudation & 8 \\
\hline PEG & Oak & $\begin{array}{l}\mathrm{T}: 20-60{ }^{\circ} \mathrm{C} \\
\mathrm{P}: 0.1 \mathrm{MPa}\end{array}$ & $\begin{array}{l}\text { Lower moisture uptake and swelling, } \\
\text { lower stability }\end{array}$ & 4 \\
\hline
\end{tabular}

It is important to note these figures were determined before the COVID19 pandemic, which may impact many of the smaller commercial production sites around the globe. However, there is a demand for high-performance wood products within our modern society and there is still considerable research and the development into improving existing methods and advancing the understanding into emerging technologies. Given the demand for improved products, the market for modified wood is expected to grow further.

\section{ACKNOWLEDGEMENTS}

The authors hereby thank the European COST Association for their funding of COST FP1407 and for the information provided by national participants in the initial compilation of data. Support of the CT WOOD - a centre of excellence at Luleå University of Technology supported by the Swedish wood industry - is also gratefully acknowledged.

\section{DISCLAIMER}

The authors hereby declare there are no conflicts of interest associated with this article.

\section{REFERENCES}

Adebawo, F. G., Sadeghifar, H., Tilotta, D., Jameel, H., Liu, Y., and Lucia, L. (2019). Spectroscopic interrogation of the acetylation selectivity of hardwood biopolymers. Starch - Stärke, 1900086. doi:10.1002/star.201900086.

Akhtari, M. and Arefkhani, M. (2016). The effect of acetylation on physical properties of beech (Fagus orientalis) and alder (Alnus subcordata) wood. In: The Proceedings $47^{\text {th }}$ IRG Annual Meeting, Lisbon, Portugal. International Research Group on Wood Protection IRG/WP 16-40759.

Akyildiz, M.H. and Ates, S. (2008). Effect of heat treatment on equilibrium moisture content (EMC) of some wood species in Turkey. Research Journal of Agriculture and Biological Sciences 4(6): 660-665.

Alfredsen G., Fossdal, C.G., Nagy, N.E., Jellison, J., and Goodell, B. (2016). Furfurylated wood: impact on Postia placenta gene expression and oxalate crystal formation. Holzforschung 70(10): 747-962. doi:10.1515/hf-2015-0203.

Allegretti, O., Brunetti, M., Cuccui, I., Ferrari, S., Nocetti, M., and Terziev, N. (2012). Thermovacuum modification of spruce (Picea abies Karst.) and fir (Abies alba Mill.) wood. BioResources 7(3): 3656-3669. 
A Review of Wood Modification Globally - Updated Findings from COST FP1407

Altgen, D., Altgen, M., Kyyrö, S., Paajanen, O., Rautkari, L., and Mai, C. (2020a). Time dependent wettability changes on plasma treated surfaces of unmodified and thermally modified European beech wood. European Journal of Wood and Wood Products 78: 417-420. doi:10.1007/s00107-020-01505-0.

Altgen, M., Kyyrö, S., Paajanen, O., and Rautkari, L. (2020b). Resistance of thermally modified and pressurized hot water extracted Scots pine sapwood against decay by the brown rot fungus Rhodonia placenta. European Journal of Wood and Wood Products 78: 161-171. doi:10.1007/s00107-019-01482-z

Andersson, M. and Tillman, A.-M. (1989). Acetylation of jute. Effects on strength, rot resistance and hydrophobicity. Journal of Applied Polymer Science 37: 3437-3447. doi:10.1002/app.1989.070371214.

Ates, S., Akyildiz, M.H., and Ozdemir, H. (2009). Effects of heat treatment on calabrian pine (Pinus brutia ten.) wood. BioResources 4(3): 1032-1043.

Awoyemi, L. and Jones, I.P. (2011). Anatomical explanations for the changes in properties of western red cedar (Thuja plicata) wood during heat treatment. Wood Science and Technology 45: 261-267. doi:10.1007/s00226-010-0315-9.

Azeh, Y., Olatunji, G.A., Mohammed, C., and Mamza, P.A. (2013). Acetylation of wood flour from four wood species grown in Nigeria using vinegar and acetic anhydride. International Journal of Carbohydrate Chemistry 2013: Article ID 141034. doi:10.1155/2013/141034.

Barcík, Š., Gašparík, M., and Razumov, E.Y. (2015a). Effect of temperature on the color changes of wood during thermal modification. Cellulose Chemistry and Technology 49(9/10): 789-798.

Barcík, Š., Gašparík, M., and Razumov, E.Y. (2015b). Effect of thermal modification on the colour changes of oak wood. Woods Research 60(3): 385-396.

BASF. 2020. http://www.intermediates.basf.com/chemicals/glyoxal/crosslinker-in-wood-hardening (2020-03-31).

Batista, D. C., Paes, J.B., Bolzón de Muñiz, G.I., Nisgoski, S., and da Silva Oliveira, J.T. (2015). Microstructural aspects of thermally modified Eucalyptus grandis wood. Maderas. Ciencia y Tecnología 17(3): 525-532. doi:10.4067/S0718$221 X 2015005000047$.

Batista, D.C., de Muñiz, G.I.B., da Silva Oliveira, J.T., Paes, J.B., and Nisgoski, S. (2016). Effect of the Brazilian thermal modification process on the chemical composition of Eucalyptus grandis juvenile wood - Part 1: Cell wall polymers and extractives contents. Maderas. Ciencia y tecnología 18(2): 273 - 284. doi: 10.4067/S0718-221X2016005000025

Batista, D.C., da Silva Oliveira, J.T., Paes, J.B., Nisgoski, S., and de Muñiz, G.I.B. (2018). Effect of the Brazilian process of thermal modification on the physical properties of Eucalyptus grandis juvenile wood. Maderas, Cienc. tecnol. 20(4): 715-724. doi:10.4067/S0718-221X2018005041701

Beck, G., Thybring, E.E., Thygesen, L.G., and Hill, C.A.S. (2018). Characterization of moisture in acetylated and propionylated radiata pine using low-field nuclear magnetic resonance (LFNMR) relaxometry. Holzforschung 72(3): 225-233. doi:10.1515/hf-2017-0072.

Bekhta, P. and Niemz, P. (2003). Effect of high temperature on the change in color, dimensional stability and mechanical properties of spruce wood. Holzforschung 57(5): 539-546. doi:10.1515/HF.2003.080.

Biziks, V., Andersons, B., Beçkova, L., Kapača, E., and Militz, H. (2013). Changes in the microstructure of birch wood after hydrothermal treatment. Wood Science and Technology 47(4): 717-735. doi:10.1007/s00226-013-0531-1.

Bollmus, S., Bongers, F., Gellerich, A., Lankveld, C., Alexander, J., and Militz, H. (2015). Acetylation of German hardwoods, pp. 164-173. In: Hughes, M., Rautkari, L., Uimonen, T. Militz, H., and Junge, B. [eds.] The Proceeding of the Eighth European Conference on Wood Modification, Helsinki, Finland.

Bongers, F. and Beckers, E.P.J. (2003). Mechanical properties of acetylated solid wood treated on pilot scale, pp. 34 1-350. In: Van Acker, J. and C.A.S. Hill [eds.] The Proceedings of the First European Conference on Wood Modification, Ghent, Belgium.

Bongers, F. and Uphill, S.J. (2019). The potential of wood acetylation, pp. 49-57. In: van de Kuilen, J.-W. and Gard, W. [eds.] ISCHP 2019, the 7th International Scientific Conference on Hardwood Processing, Delft, The Netherlands. 
A Review of Wood Modification Globally - Updated Findings from COST FP1407

Boruszewski, P., Borysiuk, P., Mamiński, M., and Grześkiewicz, M. (2011). Gluability of thermally modified beech (Fagus silvatica L.) and birch (Betula pubescens Ehrh.) wood. Wood Material Science E Engineering 6(4): 185-189. doi:10.108 0/17480272.2011.598239.

Bremer, M., Fischer, S., Nguyen, T.C., Wagenführ, A., Phuong, L.X., and Dai, V.H. (2013). Effects of thermal modification on the properties of two Vietnamese bamboo species. Part II: Effects on chemical composition. BioResources 8(1): 981-993. doi:10.15376/biores.8.1.981-993.

Brischke, C. and Thelandersson, S. (2014). Modelling the outdoor performance of wood products - A review on existing approaches. Construction and Building Materials 66: 384-397. doi:10.1016/j.conbuildmat.2014.05.087

Burmester, A. (1973). Effect of heat-pressure treatments of semi-dry wood on its dimensional stability. Holz als Roh-und Werkstoff 31(6): 237-243. doi:10.1007/BF02607268.

Bächle, H., Zimmer, B., Windeisen, E., and Wegener, G. (2010). Evaluation of thermally modified beech and spruce wood and their properties by FT-NIR spectroscopy. Wood Science and Technology 44: 42 1-433. doi:10.1007/s00226-0100361-3.

Cai, C., Javed, M.A., Komulainen, S., Telkki, V.V., Haapala, A., and Heräjärvi, H. (2020). Effect of natural weathering on water absorption and pore size distribution in thermally modified wood determined by nuclear magnetic resonance. Cellulose 27: 4235-4247. doi: 10.1007/s10570-020-03093-x.

Callow, H.J. (1951). Acetylation of cellulose and lignin in jute fiber. Journal of the Indian Chemical Society 43: 605.

Candan, Z., Korkut, S., and Unsal, O. (2013). Effect of thermal modification by hot pressing on performance properties of paulownia wood boards. Industrial Crops and Products 45: 461-464. doi:10.1016/j.indcrop.2012.12.024.

Candelier, K., Thevenon, M.-F., Petrissans, A., Dumarcay, S., Gerardin, P., and Petrissans, M. (2016). Control of wood thermal treatment and its effects on decay resistance: a review. Annals of Forest Science 73(3), 571-583. doi: 10.1007/ s13595-016-0541-x.

Carlberg, I. (2019). Den gåtfulle Alfred, hans värld och hans pris. [The Mysterious Alfred, his World and his Prize.] Nordstedts, Stockholm, Sweden. (In Swedish)

Carvalho, D.E., Juizo, C.G.F., França, M.C., Loiola. P.L., and da Rocha, M.P. (2019). Effect of thermal modification in the natural resistance of Eucalyptus grandis and Pinus taeda woods. Revista Brasileira de Ciências Agrárias 14(1): 5606. doi:10.5039/agraria.v14ila5606.

Charani, P.R., Rovshandeh, J.M., Mohebby, B., and Ramezani, O. (2007). Influence of hydrothermal treatment on the dimensional stability of beech wood. Caspian Journal of Environmental Sciences 5(2): 125-131.

Cirule, D., Meija-Feldmane, A., Kuka, E., Andersons, B., Kurnosova, N., Antons, A., and Tuherm, H. (2016). Spectral sensitivity of thermally modified and unmodified wood. BioResources 11(1): 324-335. doi:10.15376/ biores.11.1.324-335.

de Cademartori, P.H.G., Schneid, E., Gatto, D.A., Stangerlin, D.M., and Beltrame, R. (2013a). Thermal modification of Eucalyptus grandis wood: variation of colorimetric parameters. Maderas: Ciencia y Tecnología 15(1): 57-64. doi: 10.4067/S0718-221X2013005000005.

de Cademartori, P.H.G., dos Santos, P.S.B., Serrano, L., Labidi, J., and Gatto, A. (2013b). Effect of thermal treatment on physicochemical properties of Gympie messmate wood. Industrial Crops and Products 45: 360-366. doi:10.1016/j. indcrop.2012.12.048.

Ditommaso, G., Gaff, M., Kacík, F., Sikora, A., Sethy, A., Corleto, R., Razaei, F., Kaplan, L., Kubŝ, J., Das, S., Kamboj, G., Gašparík, M., Šedivka, P., Hýsek, S., Macků, J., and Sedlecký, M. (2020). Interaction of technical and technological factors on qualitative and energy/ecological/economic indicators in the production and processing of thermally modified merbau wood. Journal of Cleaner Production 252: Article ID 1 19793. doi:10.1016/j.jclepro.2019.119793

Donahue, P. and Winandy, J.E. (2014). Development and use of AWPA/ANSI Guidance Document N - Data requirements for listing thermally modified wood in AWPA Standards. Technical Session: Wood Thermal Modification: Technical Updates and Opportunities for Collaboration. Duluth, MN. Natural Resources Research Institute. 
Dong, Y., Qin, Y., Wang, K., Yan, Y., Zhang, S., Li, J., and Zhang, S. (2016). Assessment of the performance of furfurylated wood and acetylated wood: Comparison among four fast-growing wood species. BioResources 11: 3679-3690. doi:10.15376/biores. 11.2.3679-3690.

Dreher, W.A., Goldstein, I.S., and Cramer, G.S. (1964). Mechanical properties of acetylated wood. Forest Products Journal 14: 66-68.

Duhamel du Monceau, H.L. (1767). Du Transport, de la Conservation et de la Force des Bois. [Transport, Conservation and Strength of the Woods.] L.F. Delatour, Paris, France.

Dzurenda, L. (2013). Modification of wood colour of Fagus sylvatica L. to a brown-pink shade caused by thermal treatment. Woods Research 58(3): 475-482.

Emmerich, L. (2016). Holzmodifizierung von Kiefer (Pinus sylvestris L.) mit DMDHEU und modifizierten DMDHEUVarianten im Vergleich. [Comparative study on wood modification of Scots pine (Pinus sylvestris L.) with DMDHEU and modified DMDHEU.] M.Sc. Thesis, University of Göttingen, Germany.

Emmerich, L., Bollmus, S., and Militz, H. (2019). Wood modification with DMDHEU (1.3-dimethylol-4.5dihydroxyethyleneurea) - State of the art, recent research activities and future perspectives. Wood Material Science $\mathcal{E}$ Engineering 14(1): 3-18. doi:10.1080/17480272.2017.1417907.

Espinoza, O., Buehlmann, U., and Laguarda-Mallo, M.F. (2015). Thermally modified wood: marketing strategies of U.S. producers. Bioresources, 10(4): 6942-6952. doi:10.15376/biores. 10.4.6942-6952.

Esteves, B., Domingos, I., and Pereira, H. (2008a). Pine wood modification by heat treatment in air. BioResources 3(1): 142 154. doi:10.15376/biores.3.1.142-154.

Esteves, B., Nunes, L., and Pereira, H. (2009). Furfurylation of Pinus pinaster wood, 415-418. In: Englund, F., Hill, C.A.S., Militz, H and Segerholm, B.K. [eds.] The Proceeding of the Fourth European Conference on Wood Modification, Stockholm, Sweden.

Esteves, B.M. and Pereira, H.M. (2009). Wood modification by heat treatment. A review. BioResources 4(1): 370-404. doi: 10.15376/biores.4.1.370-404.

European Committee for Standardization. (2008). Thermal modified timber - Definitions and characteristics. Technical specification no. CEN/TS 15679:2008. European Committee for Standardization, Brussels, Belgium.

European Committee for Standardization. (2013). EN 335:2013. Durability of Wood and Wood-Based Products - Use Classes: Definitions, Application to Solid Wood and Wood-Based Products. European Committee for Standardization, Brussels, Belgium.

Fodor, F., Lankveld, C., and Németh, R. (2017). Testing common hornbeam (Carpinus betulus L.) acetylated with the Accoya method under industrial conditions. iForest 10(6): 948-954. doi:10.3832/ifor2359-010.

Follrich, J., Müller, U., and Gindl, W. (2006). Effects of thermal modification on the adhesion between spruce wood (Picea abies Karst.) and a thermoplastic polymer. Holz als Roh-und Werkstoff 64(5): 373-376. Doi:10.1007/s00107-0060107-y.

Franich, R.A. (2007). The Indurite process - A review from concept to business, pp. 23-29. In: Hill, C.A.S., Jones, D. and Ormondroyd, G.A. [eds.] Proceedings of the Third European Conference on Wood Modification, Cardiff, UK.

Franich, R.A. and Anderson, K. (1998). Densification of lignocellulosic material. U.S. Patent No. 5,770,319.

Gaff, M., Kačík, F., Sandberg, D., Babiak, M., Turčani, M., Niemz, P., and Hanzlík, P. (2019). The effect of chemical changes during thermal modification of European oak and Norway spruce on elasticity properties. Composite Structures 220: 529-538. doi:10.1016/j.compstruct.2019.04.034.

Gašparík, M., Gaff, M., Kačík, F., and Sikora, A. (2019). Color and chemical changes in teak (Tectona grandis L. f.) and meranti (Shorea spp.) wood after thermal treatment. BioResources 14(2): 2667-2683. doi:10.15376/ biores. 14.2.2667-2683.

Gérardin, P. (2016). New alternatives for wood preservation based on thermal and chemical modification of wood-a review. Annals of Forest Science 73: 559-570. doi:10.1007/s13595-015-0531-4. 
A Review of Wood Modification Globally - Updated Findings from COST FP1407

Goldstein, I.S., Jeroski, E.B., Lund, A.E., Nielson, J.F., and Weaver, J.W. (1961). Acetylation of wood in lumber thickness. Forest Products Journal 8: 363-370.

Gomez-Bueso, J., Westin, M., Torgilsson, R., Olesen, P.O., and Simonson, R. (1999). Composites made from acetylated lignocellulosic fibers of different origin - Part I. Properties of dry-formed fiberboards. Holz als Roh- und Werkstoff 57(6): 433-438. doi:10.1007/s001070050069.

Grinins, J., Andersons, B., Biziks, V., Andersone, I., and Dobele, G. (2013). Analytical pyrolysis as an instrument to study the chemical transformations of hydrothermally modified wood. Journal of Analytical and Applied Pyrolysis 103: 3641. doi:10.1016/j.jaap.2012.10.016.

Gunduz, G., Aydemir, D., and Karakas, G. (2009). The effects of thermal treatment on the mechanical properties of wild pear (Pyrus elaeagnifolia Pall.) wood and changes in physical properties. Materials E Design 30: 4391-4395. doi:10.1016/j.matdes.2009.04.005.

Gurleyen, L, Ayata, U., Esteves, B., Gurleyen, T., and Cakicier, N. (2019). Effects of thermal modification of oak wood upon selected properties of coating systems. BioResources 14(1): 1838-1849. doi:10.15376/biores. 14.1.1838-1849.

Hadi, Y.S., Massijaya, M.Y., Hermawan, D., and Arinana, A. (2015). Feeding rate of termites in wood treated with borax, acetylation, polystyrene, and smoke. Journal of the Indian Academy of Wood Science 12(1): 74-80. doi:10.1007/ s13196-015-0146-2.

Hill C.A.S. (2006). Wood modification - chemical, thermal and other processes. Wiley Series in Renewable Resources, Wiley and Sons, Chichester, UK, pp. 260.

Hill, C.A.S. and Jones, D. (1996). The dimensional stabilisation of Corsican pine sapwood by reaction with carboxylic acid anhydrides: The effect of chain length. Holzforschung 50: 457-462. doi:10.1515/hfsg. 1996.50.5.457.

Hoydonckx, H. E., Van Rhijn, W.M., van Rhijn, W., Hueting, D., Tjeerdsma, B., van der Zee, M., and Van Acker, J. (2007). Renewable furfuryl resin technology for wood modification, pp. 81-86. In: Hill, C.A.S., Jones, D., Militz, H., and Ormondroyd, G.A. [eds.] The Proceeding of the Third European Conference on Wood Modification, Cardiff, UK.

Huang, J., Dufresne, A., and Lin, N. (2019). Nanocellulose: From Fundamentals to Advanced Materials. John Wiley \& Sons. Wiley-VCH Verlag GmbH \& Co. KGaA, Weinheim, Germany. pp. 504. ISBN: 978-3-527-34269-3.

Ibach, R.E. (2010). Speciality Treatments. Chapter 19. In Ross, R.J. Wood handbook - Wood as an engineering material. General Technical Report FPL-GTR-190, Forest Products Laboratory, Madison, Wisconsin, USA.

International ThermoWood Association (2018). ThermoWood production statistics 2017. Downloaded (18/06/2018) from: https://asiakas.kotisivukone.com/files/en.thermowood. palvelee.fi/uutiset/Productionstatistics2017.pdf

Jawaid, M., Sapuan Salit, M., and Alothman, O.Y. (2017). Green Biocomposites: Design and Applications. Springer International Publishing AG, Cham, Switzerland. ISBN: 978-3-319-46609-5.

Jebrane, M., Pichavant, F., and Sèbe, G. (2011). A comparative study on the acetylation of wood by reaction with vinyl acetate and acetic anhydride. Carbohydrate Polymers 83(2): 339-345. doi:10.1016/j.carbpol.2010.07.035.

Jones, D., Sandberg, D., Goli, G., and Todaro, L. (2019). Wood Modification in Europe. A state-of-the-art about processes, products and applications. University of Firenze, Italy. ISSN 2704-601X (print) - ISSN 2704-5846 (online).

Kačíková, D., Kačík, F., Čabalová, I., and Duurkovič, J. (2013). Effects of thermal treatment on chemical, mechanical and colour traits in Norway spruce wood. BioResource Technology 144: 669-674. doi:10.1016/j.biortech.2013.06.110.

Kaygin, B., Gunduz, G., and Aydemir, D. (2009). Some physical properties of heat-treated paulownia (Paulownia elongata) wood. Drying Technology 27(1): 89-93. doi:10.1080/07373930802565921.

Kebony. (2020). https://kebony.com/en (access date 2020-03-22).

Kekkonen, P.M., Telkki, V.-V., and Jokisaari, J. (2010). Effect of thermal modification on wood cell structures observed by pulsed-field-gradient stimulated-echo NMR. The Journal of Physical Chemistry C 114(43): 18693-18697. doi: $10.1021 / \mathrm{jp} 1060304$.

Kol, H.Ş. and Sefil, Y. (2011). The thermal conductivity of fir and beech wood heat treated at 170, 180, 190, 200, and 212․ Journal of Applied Polymer Science 121(4): 2473-2480. doi:10.1002/app.33885. 
A Review of Wood Modification Globally - Updated Findings from COST FP1407

Korkut, D.S. and Guller, B. (2008). The effects of heat treatment on physical properties and surface roughness of red-bud maple (Acer trautvetteri Medw.) wood. BioResource Technology 99: 2846-2851. doi:10.1016/j.biortech.2007.06.043.

Korkut, S. and Hiziroglu, S. (2009). Effect of heat treatment on mechanical properties of hazelnut wood (Corylus colurna L.). Materials E Design 30: 1853-1858. doi:10.1016/j.matdes.2008.07.009.

Korkut, S., Kök, M.S., Korkut, D.S., and Gürleyen, T. (2008a). The effects of heat treatment on technological properties in red-bud maple (Acer trautvetteri Medw.) wood. BioResource Technology 99: 1538-1543. doi:10.1016/j. biortech.2007.04.021.

Korkut, S., Akgüla, M., and Dündar, T. (2008b). The effects of heat treatment on some technological properties of Scots pine (Pinus sylvestris L.) wood. BioResource Technology 99: 1861-1868. doi:10.1016/j.biortech.2007.03.038.

Korkut, S., Korkut, D.S., Kocaefe, D., Elustondo, D., Bajraktari, A.C., and Cakicier, N. (2012). Effect of thermal modification on the properties of narrow-leaved ash and chestnut. Industrial Crops and Products 35(1): 287-294. doi:10.1016/j.indcrop.2011.04.024.

Kotilainen, R.A., Toivanen, T.-J., and Alén, R.J. (2008). FTIR monitoring of chemical changes in softwood during heating. Journal of Wood Chemistry and Technology 20(3): 307-320. doi:10.1080/02773810009349638.

Kubovský, I., Kačíková, D. and Kačík, F. (2020). Structural Changes of Oak Wood Main Components Caused by Thermal Modification. Polymers 12(2): 485. doi: 10.3390/polym 12020485.

Kučerová, V., Lagaňa, R., and Hýrošová, T. (2019). Changes in chemical and optical properties of silver fir (Abies alba L.) wood due to thermal treatment. Journal of Wood Science 65: 21-31. doi:10.1186/s10086-019-1800-x.

Källander, B. (2016). Drying and thermal modification of wood: Studies on influence of sample size, batch size, and climate on wood response. PhD. Thesis, Luleå University of Technology, Skellefteå, Sweden.

Lande, S., Westin, M., and Schneider, M. (2004). Properties of furfurylated wood. Scandinavian Journal of Forest Research 19(5): 22-30. doi:10.1080/0282758041001915.

Lande, S., Eikenes, M., Westin, M., and Schneider, M. (2008). Furfurylation of wood: chemistry, properties and commercialization. In: Development of Commercial Wood Preservatives. (Schultz TP, Militz H, Freeman MH, Nicholas DD eds). ACS Symposium Series 982: 337-355. doi:10.1021/bk-2008-0982.ch020.

Larsson, P. and Simonson, R. (1994). A study of strength, hardness and deformation of acetylated Scandinavian softwoods. Holz als Roh-und Werkstoff 52(2): 83-86. doi:10.1007/BF02615470.

Larsson-Brelid, P. and Simonson, R. (1999). Acetylation of solid wood using microwave heating Part 2. Experiments in laboratory scale. Holz als Roh- und Werkstoff 57(5): 383-389. doi:10.1007/s001070050364.

Lekounougou, S. and Kocaefe, D. (2014). Effect of thermal modification temperature on the mechanical properties, dimensional stability, and biological durability of black spruce (Picea mariana). Wood Material Science E Engineering 9(2): 59-66. doi: 10.1080/17480272.2013.869256.

Li, W., Ren, D., Zhang, X., Wang, H., and Yu, Y. (2016). The furfurylation of wood: A nanomechanical study of modified wood cells. BioResources 11(2): 3614-3625. doi:10.15376/biores.11.2.3614-3625.

Ling, Z., Ji, Z., Ding, D., Cao, J., and Xu, F. (2016). Microstructural and topochemical characterization of thermally modified poplar (Populus cathayaha) cell wall. BioResources 11(1): 786-799. doi:10.15376/biores.1 1.1.786-799.

Lowden, L.A. and Hull, T.R. (2013). Flammability behaviour of wood and a review of the methods for its reduction. Fire Science Reviews 2(4): 1-19. doi:10.1186/2193-0414-2-4.

Majka, J. and Roszyk, E. (2018). Swelling restraint of thermally modified ash wood perpendicular to the grain. European Journal of Wood and Wood Products 76: 1129-1136. doi:10.1007/s00107-018-1321-0.

Manalo, R.D. and Garcia, C.M. (2012). Termite resistance of thermally-modified Dendrocalamus asper (Schultes f.) Backer ex Heyne. Insects 3: 390-395. doi: 10.3390/insects3020390.

Mantanis, G.I. (2017). Chemical modification of wood by acetylation and furfurylation: A review of the present scaled-up technologies. BioResources 12(2): 4478-4489. Doi:10.15376/biores.12.2.4478-4489. 
Matsunaga, M., Kataoka, Y., Matsunaga, H., and Matsui, H. (2010). A novel method of acetylation of wood using supercritical carbon dioxide. Journal of Wood Science 56(4): 293-298. doi:10.1007/s10086-009-1098-1.

Meluna, A.J. (ed.) (2009). Documents of Life and Activity of the Nobel Family 1801 - 1032. Volume 1. J.S.C. Humanistica, St. Petersburg, Russia. (In Russian)

Militz, H. (1991a). Die Verbesserung des Schwind- und Quellverhaltens und der Dauerhaftigkeit von Holz mittels Behandlung mit unkatalysiertem Essigs iureanhydrid. [The improvement of dimensional stability and durability of wood through treatment with non-catalysed acetic-acid anhydride]. Holz als Roh-und Werkstoff 49: 147-152.

Militz, H. (1991b). Improvements of stability and durability of beech wood (Fagus sylvatica) by means of treatment with acetic anhydride. In: The Proceedings $41^{\text {st }} I R G$ Annual Meeting, Biarritz, France. International Research Group on Wood Protection IRG/WP/3645.

Militz, H. (2015). Wood modification in Europe in the year 2015: a success story? Proceedings of the 8th European Conference of Wood Modification, 26-27 Oct. Aalto University, Finland.

Morrell, J.J. (2018). What is wrong with wood modification in the U.S.?. Proceedings of the $9^{\text {th }}$ European Conference of Wood Modification, 17-18 September, Arnhem, The Netherlands, p 32-38.

Navi, P. and Sandberg, D. (2012). Thermo-hydro-mechanical processing of wood. EPFL Press, Lausanne, Switzerland.

Németh, R., Gohér, G., Hofmann, T., and Rákosa, R. (2010). Physical, mechanical and colour properties of acetylated poplar and robinia wood, pp. 231. In: Kúdela, J. and Lagana, R. [eds.] Proceedings of 6th IUFRO Symposium "Wood Structure and Properties 10". Podbanské, Slovakia. Arbora Publishers.

Nguyen, C.T., Wagenführ, A., Phuong, L.X., Dai, V.H., Bremer, M., and Fischer, S. (2012). The effects of thermal modification on the properties of two Vietnamese bamboo species. Part I: Effects on physical properties. BioResources 7(4): 5355-5366. doi:10.15376/biores.7.4.5355-5366.

Nhacila Jr., F., Sitoe, Uetimane Jr., E., Manhica, A., Egas, A., and Möttönen, V. (2019). Effect of thermal modification on physical and mechanical properties of Brachystegia spiciformis and Julbernardia globiflora from Mozambique. Proceedings 7 th International Scientific Conference on Hardwood Processing (ISCHP) 35-42 (Ed. van der Kuilen, J.W. and W. Gard).

Nordstierna, L., Lande, S., Westin, M., Karlsson, O., and Furo, I. (2008). Towards novel wood-based materials: chemical bonds between lignin-like model molecules and poly (furfuryl alcohol) studied by NMR. Holzforschung 62(6): 709713. doi:10.1515/HF.2008.110.

Nordin, N.I.A.A., Ariffin, H., Andou, Y., Hassan, M.A., Shirai, Y., Nishida, H., Yunus, W.M.Z.W., Karuppuchamy, S., and Ibrahim, N.A. (2013). Modification of oil palm mesocarp fiber characteristics using superheated steam treatment. Molecules 18: 9132-9146. doi:10.3390/molecules 18089132

Ozmen, N. (2007). Dimensional stabilization of fast growing forest species by acetylation. Journal of Applied Sciences 7: 710-714.

Pelaez-Samaniego, M. R., Yadama, V., Lowell, E., and Espinoza-Herrera, R. (2013). A review of wood thermal pretreatments to improve wood composite properties. Wood Science and Technology 47(6), 1285-1319. doi:10.1007/ s00226-013-0574-3.

Pilgård, A., Treu, A., Zeeland, A.N., Gosselink, R.J., and Westin, M. (2010). Toxic hazard and chemical analysis of leachates from furfurylated wood. Environmental Toxicology and Chemistry 29(9): 1918-1924. doi:10.1002/etc.244.

Popescu, C.-M. and Popescu, M.-C. (2013). A near infrared spectroscopic study of the structural modifications of lime (Tilia cordata Mill.) wood during hydro-thermal treatment. Spectrochimica Acta Part A: Molecular and Biomolecular Spectroscopy 115: 227-233. doi:10.1016/j.saa.2013.06.002.

Popescu, M.-C., Froidevaux, J., Navi, P., and Popescu, C.-M. (2013a). Structural modifications of Tilia cordata wood during heat treatment investigated by FT-IR and 2D IR correlation spectroscopy. Journal of Molecular Structure 1033: 176-186. doi:10.1016/j.molstruc.2012.08.035. 
A Review of Wood Modification Globally - Updated Findings from COST FP1407

Popescu, M.-C., Demco, D.E., and Möller, M. (2013b). Solid state 13C CP/MAS NMR spectroscopy assessment of historic lime wood. Polymer Degradation and Stability 98(12): 2730-2734. doi:10.1016/j. polymdegradstab.2013.10.006.

Popescu, C.-M., Hill, C.A.S., Curling, S.F., Ormondroyd, G.A., and Xie, Y. (2014). The water vapor sorption behaviour of acetylated birch wood. How acetylation affects the sorption isotherm and accessible hydroxyl content. Journal of Material Science 49(5): 2362-2371. doi:10.1007/s10853-013-7937-x.

Puttmann, S., Krause, A., Pilgård, A., Treu, A., and Militz, H. (2009). Furfurylated wood for wooden window constructions, pp. 569-576. In: Englund, F., Hill, C.A.S., Militz, H., and Segerholm, B.K. [eds.] The Proceeding of the Fourth European Conference on Wood Modification, Stockholm, Sweden.

Rafidah, K.S., Hill, C.A.S., and Ormondroyd, G.A. (2006). Dimensional stabilization of rubberwood (Hevea brasiliensis) with acetic or hexanoic anhydride. Journal of Tropical Forest Science 18: 261-268.

Rapp. A.O. (2001). Review on heat treatments of wood. COST Action E22 "Environmental optimisation of wood protection”. Proceedings of special seminar, Antibes, France. 9 February 2001.

Ringman, R., Pilgård, A., and Richter, K. (2020). Brown rot gene expression and regulation in acetylated and furfurylated wood: A complex picture. Holzforschung 74(4): 301-399. doi:10.1515/hf-2019-0031.

Rowell, R.M. (1983). Chemical modification of wood. Forest Products Abstracts 6(12): 363-382.

Rowell, R.M. (1984). Penetration and Reactivity of Cell Wall Components, pp. 175-210. In: Rowell, R.M. [ed.]. The Chemistry of Solid Wood. American Chemical Society, Washington, DC, USA.

Rowell, R.M. and Harrison, S.E. (1993). Property enhanced kenaf fiber composites, pp. 129-136. In: Bhangoo, M.S. [ed.] Proceedings of the Fifth Annual International Kenaf Conference, California State University Press, Fresno (CA), USA.

Rowell, R.M. and Keany, F.M. (1991). Fibreboard made from acetylated bagasse fiber. Wood and Fiber Science 23(1): 15 22.

Rowell, R.M. and Norimoto, M. (1987). Acetylation of bamboo fiber. Aspen Bibliography, Article ID 3469.

Rowell, R.M. and Plackett, D.V. (1988). Dimensional stability of flakeboards made from acetylated Pinus radiata heartwood or sapwood flakes. New Zealand Journal of Forestry Science 18: 124-131.

Rowell, R.M. and Rowell, J.S. (1989). Moisture sorption of various types of acetylated lignocellulosic fibers. Cellulose and Wood. In: Schuerch, C. [ed.] John Wiley and Sons, New York, USA.

Sandberg, D. and Kutnar, A. (2016). Thermal modified timber: recent developments in Europe and North America. Wood and Fiber Science 48 (1): 28-39.

Sandberg, D., Kutnar, A., and Mantanis, G.I. (2017). Wood modification technologies - a review. iForest 10: 895-908. doi:10.3832/ifor2380-010.

Schindler, W.D. and Hauser, P.J. (2004). Chemical Finishing of Textiles. Woodhead, Cambridge, UK.

Sejati, P.S., Imbert, A., Gérardin-Charbonnier, C., Dumarçay, S., Fredon, E., Masson, E., Nandika, D., Priadi, T., and Gérardin, P. (2017). Tartaric acid catalyzed furfurylation of beech wood. Wood Science and Technology 5 1(2): 379 394. doi:10.1007/s00226-016-0871-8.

Sikora, A., Kač, F., Gaff, M., Vondrov, V., Buben, T., and Kubovský, I. (2018). Impact of thermal modification on color and chemical changes of spruce and oak wood. Journal of Wood Science 64: 406-416. doi:10.1007/s10086-018-1721-0.

Skrede, I., Solbakken, M.H., Hess, J., Fossdal, C.G., Hegnar, O., and Alfredsen, G. (2019). Wood modifcation by furfuryl alcohol resulted in a delayed decomposition response in Rhodonia (Postia) placenta. Applied and Environmental Microbiology 85(14): 1-21. doi:10.1128/AEM.00338-19.

Srinivas, K. and Pandey, K.K. (2012). Effect of heat treatment on color changes, dimensional stability, and mechanical properties of wood. Journal of Wood Chemistry and Technology 32(4): 304-316.

Stamm, A.J. and Seborg, R.M. (1943). Resin treated wood (Impreg). Lab. Report No. 1380, US Department of Agriculture, Forest Service, Forest Products Laboratory, Madison (WI), USA. 
A Review of Wood Modification Globally - Updated Findings from COST FP1407

Stamm, A.J. and Seborg, R.M. (1944). Resin treated laminated com- pressed wood (Compreg). Lab. Report No. 1381, US Department of Agriculture, Forest Service, Forest Products Laboratory, Madison (WI), USA.

Stefanowski, B., Spear, M. and Pitman, A. (2018). Review of the use of PF and related resins for modification of solid wood. In M. Spear (Ed.), Timber 2018 (pp. 165-179). London.

Subagiyo, L., Rosamah, E., and Hesim. (2017). Modification of oil palm wood using acetylation and impregnation process, 6 pp. In: - [eds.] AIP Conference Proceedings 1823.

Sun, R.C. and Sun, X.F. (2002). Structural and thermal characterization of acetylated rice, wheat, rye, and barley straws and poplar wood fibre. Industrial Crops and Products 16(3): 225-235.

Sun, X.F. and Sun, R.C. (2002). Comparative study of acetylation of rice straw fiber with or without catalysts. Wood and Fiber Science 34(2): 306-317.

Thybring, E.E., Thygesen, L.G., Svensson, S., and Hill, C.A.S. (2013). A critical discussion of the physics of wood-water interactions. Wood Science and Technology 47(1): 141-161. doi:10.1007/s00226-012-05 14-7.

Thygesen, L.G., Barsberg, S., and Venås, T.M. (2010). The fluorescence characteristics of furfurylated wood studied by fluorescence spectroscopy and confocal laser scanning microscopy. Wood Science and Technology 44: 51-65. doi: 10.1007/s00226-009-0255-4.

Todorović, N., Popović, Z., and Milić, G. (2015). Estimation of quality of thermally modified beech wood with red heartwood by FT-NIR spectroscopy. Wood Science and Technology 49(3): 527-549. doi:10.1007/s00226-015-0710-3.

Tolf, A.W. (1976). The Russian Rockefellers: The saga of the Nobel family and the Russian oil. Publ. No. 158, Hoover Institution Press, Stanford University, Stanford (CA), USA.

Tredgold, T. (1820). Elementary Principles of Carpentry. J. Taylor, High Holburn, UK.

Tuong, V.M. and Li, J. (2011). Changes caused by heat treatment in chemical composition and some physical properties of acacia hybrid sapwood. Holzforschung 65(1): 67-72. doi:10.1515/hf.2010.118.

Unger, A., Schniewind, A.P., and Unger, W. (2001). Conservation of Wood Artifacts - A Handbook. Springer-Verlag, Berlin, Heidelberg, Germany. ISBN 978-3-662-06398-9.

Venås, T.M. and Wong, A.H.H. (2008). Feasibility study on three furfurylated non-durable tropical wood species evaluated for resistance to brown, white and soft rot fungi. In: The Proceedings 39 th IRG Annual Meeting, Istanbul, Turkey. International Research Group on Wood Protection IRG/WP 08-40395.

Visakh, P.M. and Arao, Y. (2015). Flame retardants: Polymer blends, composites and nanocomposites. Springer International Publishing, Cham, Switzerland. ISBN: 978-3-319-03466-9.

Wang, W., Zhu, Y., Cao, J., and Sun, W. (2015). Correlation between dynamic wetting behavior and chemical components of thermally modified wood. Applied Surface Science 324(1): 332-338. doi:10.1016/j.apsusc.2014.10.139.

Wikberg, H. and Maunu, S. (2004). Characterisation of thermally modified hard- and softwoods by 13C CPMAS NMR. Carbohydrate Polymers 58(4): 461-466. doi:10.1016/j.carbpol.2004.08.008.

Willems, W., Altgen, M., and Rautkari, L. (2020). A molecular model for reversible and irreversible hygroscopicity changes by thermal wood modification. Holzforschung 74(4): 420-425. doi:10.1515/hf-2019-0057.

WPA (2012). Manual: Industrial Wood Preservation - Specification and Practice. UK Wood Protection Association, Castleford, UK.

Wålinder, M., Brelid, P.L., Segerholm, K., Long II, C.J. and Dickerson, J.P. (2013). Wettability of acetylated Southern yellow pine. International Wood Products Journal 4(3): 197-203. doi:10.1179/2042645313Y.0000000045.

Yalcin, M. and Sahin, H.I. (2015). Changes in the chemical structure and decay resistance of heat-treated narrow-leaved ash wood. Maderas: Ciencia y Tecnologia 17(2): 435-446. doi:10.4067/S0718-221X2015005000040.

Yang, T., Ma, E., and Cao, J. (2019). Synergistic effects of partial hemicellulose removal and furfurylation on improving the dimensional stability of poplar wood tested under dynamic conditions. Industrial Crops \& Products 139: Article ID 111550. doi:10.1016/j.indcrop.2019.111550. 
Yildiz, S., Yildiz, U.C., and Tomak, E.D. (2011). The effects of natural weathering on the properties of heat-treated alder wood. BioResources 6(3): 2504-2521. doi:10.15376/biores.6.3.2504-2521.

Yildiz, U.C., Yildiz, S., and Gezer, E.D. (2005). Mechanical and chemical behavior of beech wood modified by heat. Wood and Fiber Science 37(3): 456-461.

Zelinka, S.L., Kirker, G.T., Bishell, A.B., and Glass, S.V. (2020). Effects of wood moisture content and the level of acetylation on brown rot decay. Forests 11(299): 1-10. doi:10.3390/f1 1030299. 